
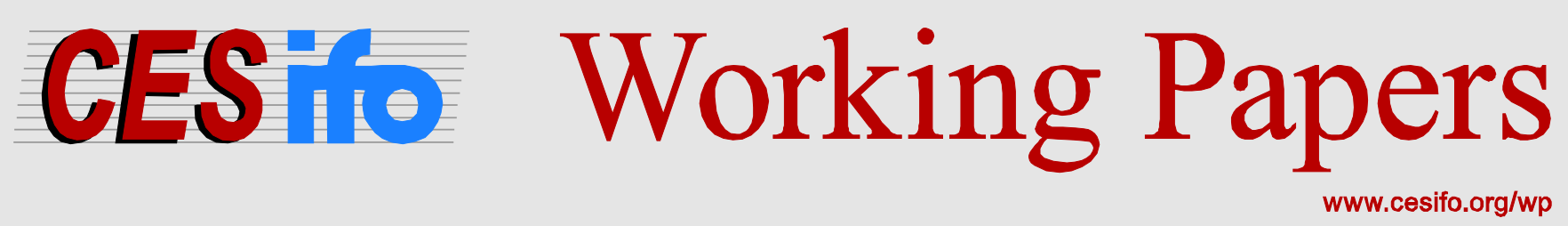

\title{
Malthus Meets Luther: The Economics Behind the German Reformation
}

\author{
Malik Curuk \\ Sjak Smulders
}

\author{
CESIFO WORKING PAPER NO. 6010 \\ CATEgory 6: FisCAl POLICY, MaCROECONOMICS AND GROWTH \\ JULY 2016
}

An electronic version of the paper may be downloaded

- from the SSRN website:

- from the RePEc website:

- from the CESifo website:

WwW.SSRN.com

Www.RePEc.org

www.CESifo-group.org/wp 


\title{
Malthus Meets Luther: The Economics Behind the German Reformation
}

\begin{abstract}
The Reformation provided a powerful source of legitimacy for secularization of governance and enabled the regional authorities to change the institutional structure to eliminate the inefficiencies under the prevailing (Catholic) regime. We investigate this idea in a simple model of regime change and show that the regions where the prevailing institutions are less appropriate, i.e. poorer regions with greater economic potential, should have been more likely to adopt the Reformation. Using detailed data on religious denominations, city characteristics and exogenous measures of agricultural potential, we empirically confirm this hypothesis for the cities in the $16^{\text {th }}$ century Holy Roman Empire. This finding points to an economic rationale of the adoption of Protestantism as a vehicle of institutional change.
\end{abstract}

JEL-Codes: D720, N330, N430, N530, Z120.

Keywords: institutional change, appropriate institutions, Malthusian growth, economics of religion, German Reformation, regional autonomy, agricultural potential, urbanization.

\author{
Malik Curuk \\ Tilburg University \\ Department of Economics \\ PO Box 90153 \\ The Netherlands - 5000 LE Tilburg \\ M.Curuk@uvt.nl
}

\author{
Sjak Smulders \\ Tilburg University \\ Department of Economics \\ PO Box 90153
}

The Netherlands - 5000 LE Tilburg

J.A.Smulders@uvt.nl

July 15, 2016

We thank Sascha Becker, Maarten Bosker, Davide Cantoni, Carl-Johan Dalgaard, Klaus Desmet, Oded Galor, Gabriel Felbermayr, James Fenske, Holger Strulik, Jan Luiten van Zanden and participants in various seminar and conferences for helpful suggestions. Hans Torben Löfflad provided valuable research assistance. 


\section{Introduction}

If I had never taught or done anything else than I had enhanced and illuminated secular rule and authority... this alone should deserve thanks... Since the time of the apostles no doctor or writer, no theologian or lawyer has confirmed, instructed, and comforted secular authority more glorious and clearly than I was able to do through special divine grace.

Martin Luther, $1533^{1}$

Political and social institutions are deeply rooted in history. Even when powerful forces in society would demand for institutional changes, drastic changes in institutions are infrequent events. One reason might be that the need for change builds up gradually, which allows vested interests to adapt to changing conditions and stay in power. True shifts in power might arise when incumbent rulers overlook or underestimate socioeconomic developments, or when unexpected shocks occur. The combination of economic forces building up and historical unique events seems to be a plausible candidate explanation behind major institutional changes as the rise of democracy, abolition of slavery, and introduction of a market economy after communism.

In this paper, we study the economic determinants of one of the most influential institutional changes in European history which had enormous impact on the economic, cultural and political evolution of Europe: the Reformation. Since Weber's famous work "Protestant Ethic and the Spirit of Capitalism", it has been argued that Protestantism was a crucial element, if not the driving force, in creating the necessary context for wealth and human capital accumulation which eventually fostered the rise of modern economic and political systems (see Hill (1961), Blum and Dudley (2001), Arruñada (2010) and Becker and Woessmann (2009) among many

\footnotetext{
${ }^{1}$ Quoted in Brady (2007), p. 22, translated from Luther, "Verantwortung der aufgelegten Aufruhr von Herzog Georg (1533)", reprinted in D. Martin Luthers Werke, Weimar: Hermann Boehlaus Nachfolger 1912, vol. 38, p. 102-103.
} 
others). In line with the recent literature summarized in Becker, Pfaff, and Rubin (forthcoming), we go back one stage and look into the causes of the Reformation. ${ }^{2}$

We advance the hypothesis that Protestantism provided a powerful source of legitimacy for secularization of governance and enabled the regional/local authorities to change the institutional structure to eliminate the inefficiencies under the prevailing (Catholic) regime. We investigate this idea in a model of regime change and show that the regions where the prevailing institutions are less appropriate, i.e. poorer regions with greater economic potential, should have been more likely to adopt the Reformation. Then, using detailed data on religious denominations, city characteristics and exogenous measures of agricultural potential, we empirically confirm the hypothesis that the likelihood of conversion to Protestantism was higher in poorer regions with higher economic potential in the 16th century Holy Roman Empire.

The link between institutions and the doctrines of the new religion is very tangible in the historical record and a brief sketch of it shows the relevance for the economic and political situation. With the Reformation in Western Europe in the 16th century, not only a new religious denomination came into being, with major consequences for ideology and social values. It also coincided with political shifts for which the tensions had been building up for a long period within the patchwork of German territories - princedoms, prince-bishoprics, and free cities - and in the context of a complex balance of power and privileges in relation to the Holy Roman Empire.

While formally the emperor was the central authority in the German lands, his position was fragile by nature - because he was dependent on being elected by the prince-electors - and increasingly weak in practice compared to more centralized states like France and England. Outside his own domains, the emperor could raise taxes or collect armies only in emergency situations. The attempts of the territorial princes and urban magistrates to restrict the imperial authority in political and fiscal

\footnotetext{
${ }^{2}$ Our earlier results are summarized in this survey article; and they remain the same in the larger dataset and various robustness checks we present in this paper.
} 
matters intensified by the turn of the sixteenth century and was reflected in a series of imperial diets (Reichstag) from the Diet of Worms (1495) to the Peace of Augsburg (1555) and finally to the Peace of Westphalia (1648), which marks the birth of the nation-state. By the Peace of Westphalia, the protracted process of increasing regional autonomy was crowned with a formal agreement on the mutual recognition of regional sovereignties. The political climate which Protestantism was born into was, to an important extent, characterized by urgent demand for constitutional reform to achieve higher regional autonomy. ${ }^{3}$

The local princes, as well as the free imperial cities, had probably even more to gain from local institutional changes. Their own power was rather weak since in the semi-feudal society law was still largely personal rather than territorial and the princes had to compete with ecclesiastic and municipal courts for jurisdiction (Nicholas (2009)). For example, eight different patrons - some secular, some from the church - held the patronage rights in the eighteen rural parishes of Swabisch Hall, which severely limited control over the villages. This makes Scribner (1994, p. 24) to conclude that "[a] major goal of German politics at all levels well before the Reformation was to submit the church and its agencies to secular control."

As Luther himself stated, Protestantism can be considered as an expression of demand for worldly rule in a scriptural context. Under the Catholic rule, the idea of final authority was prevailing. God was the authority, his status was expressed on earth by the Pope and represented by the Emperor. Therefore, legitimizing the sovereignty of the regional rulers as opposed to the universality claims by the Catholic Church should have required an alternative narrative for the representation of the final authority. Luther's doctrine of justification by faith alone (sola fide) undermined the role of the Catholic Church as the monopoly on worldly affairs and

\footnotetext{
${ }^{3}$ While discussing the evolution of fiscal structure in the Holy Roman Empire, Eberhard Isenmann (1999) identifies the fundamental reasons driving this process as follows: It was the coincidence of long-term financial and political decline with a new, severe and almost permanent military threat and an urgent demand for constitutional reform in the fifteenth century that created the context in which early modern taxation would develop.
} 
the role of clergy as a separate privileged social class (Bonney (1991), p.18).

The Lutheran view was from the beginning that spiritual life is individual and separate from the institutionalized church which should be governed by the laws of the Christian prince and his councilors. It implied that a wide range of institutions which govern daily economic life were consigned to civil authority. Lutheran urban councils enacted church ordinances to regulate matters that previously had been within the competence of the Roman Catholic Church, viz. marriage ordinances, governing marriage and family relations; disciplinary ordinances, governing moral offenses; school ordinances, governing public education of children; and poor ordinances, governing relief of the poor, the sick, widows and orphans, the homeless, the unemployed (Berman (2009)). Clergy became civil servants, while monasteries were dissolved. Former monastery buildings housed universities that educated legal scholars of a new style, who as councilors of the regional authorities helped to pave the way to a more professional and centralized state apparatus. Thus the Reformation created more state control (cf. Tilly (1992)). The Reformation appealed to all strata of society, but eventually concentrated power and de facto property rights at the regional level. This concentration became possible by the elimination of the old church rights and achieving tighter control of social and economic life, both in rural and urban realms. As a popular rural movement, the peasants' war (1524-1525) turned out to be unsuccessful. ${ }^{4}$ In the urban setting, civil authorities frequently used their newly gained power to suspend dissident clergy from office (e.g. Wolfart $(2002))$.

While Luther's doctrine could justify aspirations of local rulers, it still leaves us with the question which rulers actually exploited this opportunity. We start from the premise that economic factors influence the rulers' decision. The conversion of a region to a new religion shifts the balance of powers, both within the region and in relation to interregional levels of the political hierarchy. The conversion

\footnotetext{
${ }^{4}$ Related to this movement, Luther condemned violence against the Christian princes based on the principle of Render unto Ceasar in Against the Murderous, Thieving Hordes of Peasants in May 1525.
} 
allows for a shift in the rules and institutions, which facilitates taking up economic opportunities. We hypothesize that regions that would benefit most from a shift in power and institutions are more likely to adopt the Reformation.

In the case of adoption of Protestantism in Germany after 1517, the potential economic benefits should be evaluated in the context of a mainly agriculture-based Malthusian economy with merchant activities in the cities. Small population density in fertile lands might indicate that the prevailing (Catholic) institutions fail to realize the potential, which gives local rulers the incentive to break with the old church and old institutions to start using the potential. ${ }^{5}$

The institutions that determine productivity in agriculture are related to the management of often communal- fields by village councils and manorial lords. Where land reform and shifts in rotation schemes could improve productivity, fragmented ownership created vested interests that blocked reform. The change toward concentrated authority increased the scope for reform. ${ }^{6}$ A similar link between more effective power and necessary reform to exploit opportunities can be identified in

\footnotetext{
${ }^{5}$ The role of economic factors in the Reformation has been stressed before by historians. We quote Bonney (1991), p. 15-16: "It was crucial to the history of the Reformation that Luther was not silenced, as John Hus had been (by burning). Luther had a powerful, if an unexpected, protector. Elector Frederick the Wise of (Ernestine) Saxony was a paragon of late medieval piety. If he ever read Luther's ninety-five theses about indulgences, he would have had some qualms about offering his support, chiefly since he himself had accumulated Papal indulgences for 127799 years in purgatory. But politics, rather than religious belief governed the elector's behaviour. He [Elector Frederick the Wise of (Ernestine) Saxony] was a political opponent of Cardinal Albrecht von Hohenzollern, and had banned Johann Tetzel from selling indulgences in his lands. He had another, financial, motive: he wanted to keep Saxon money at home. There was to be no competition with his local shrine, and no money leaving the duchy for Rome... Finally, as with all the princes of the Holy Roman Empire, he wanted to maintain his independence from the Emperor."

${ }^{6}$ There are few reliable contemporaneous sources about agricultural improvements in connection with the reformation. One remarkable example can be found in the chronicle of an exiled German farmer (Bergsma and Waterbolk (1986)). Just after the anonymous author praises Luther and his rebellion against the pope and emperor and mentions the spread of the protestant faith in the area where he lives, he states that his time has witnessed important innovations and improvements in agriculture.
} 
the context of merchant guilds and commerce in the cities.

We demonstrate the role of potential benefits from institutional change in a simple model of regime change where adopting Protestantism is a rational choice of the ruler given the economic fundamentals: agricultural potential, land endowment, and the institutional appropriateness. In this setting Reformation is a risky decision due to the uncertainty of being successful and costly due to the inefficient of use of productive factors during transition. On the other hand, conditional on being successful it enables the ruler (or the ruling elite) to device more appropriate institutions and increase the regional output and tax base. We show that there is a cut-off value of institutional appropriateness under which conversion to the new religion is the optimal response of the output-maximizing regional ruler. Since the appropriateness of institutions is not directly observable, we use the Malthusian structure of the economy to express the appropriateness of institutions in terms of agricultural potential and population levels. Given the population level, higher agricultural potential signals worse institutions and untapped economic potential whereas conditional on the agricultural potential a high population level implies a relatively well functioning economic system and more appropriate institutions. Hence, the likelihood of adopting Protestantism is higher in the regions with higher agricultural potential and lower population.

Using data on the adoption of Protestantism in the Holy Roman Empire and an exogenous measure of agricultural potential based on the climatic conditions and the soil quality of a region, we empirically show that agricultural potential is a very robust and strong determinant of conversion decisions of the rulers. Controlling for various characteristics which might determine the rulers' incentives, we find that one standard deviation increase in agricultural potential increases the probability of adopting Protestantism by 14.7 percentage points. Furthermore, population level appears to be significant with a negative sign, which is also consistent with our hypothesis. Everything else constant, one standard deviation increase in the (logged) urban population of a region decreases the probability of conversion to Protestantism by 11.5 percentage points. 
Our theory and evidence on the economic roots of the German reformation are related to the literature on endogenous institutions. Several mechanisms behind sudden or gradual changes in institutions have been discussed, ranging from economic class struggle and vested interests (Brenner (1993), Acemoglu, Johnson, and Robinson (2005)) to internal dynamics of governance structures (Greif and Laitin (2004)) and critical junctions (Capoccia and Kelemen (2007)). In the tradition of the latter we argue that Luther's doctrines made possible a major shift in power for which the forces had been build up before, while we show within the tradition of former theories that the Reformation was a rational response of the local authorities given the economic implications of the Catholic and Protestant principles of governance. Our case of Germany complements the study of the Glorious revolution and the rise of parliaments in England, which was explicitly linked to endogenous choice of religion by Greif and Rubin (2014) and of the building of state and legal capacity (Besley and Persson (2009)).

A related line of literature argues that changes in the institutional structure lead to superior economic outcomes as long as they are appropriate for the specificities of countries (Berkowitz, Pistor, and Richard (2003) and Rodrik (2008)). Consistent with this idea, we show that the dissolution of an institutional structure begins where it is the least appropriate, i.e. poorer regions with higher economic potential. In the light of this finding, the comparative development of German cities across different religious denominations might be perceived as an example of the Reversal of Fortune enabled by the rise of the Reformation. ${ }^{7}$

Our paper adds an economic (Malthusian) dimension to the recent literature examining the determinants of the adoption of Protestantism (Pfaff and Corcoran

\footnotetext{
${ }^{7}$ Whether Protestantism fostered economic progress is a controversial issue (see e.g. Becker and Woessmann (2009) and Cantoni (2014)). Although it is beyond the scope of this paper to settle down this debate, we observe that protestant regions exhibited stronger urbanization after the Reformation across the cities considered in our dataset. The share of protestant regions in the total urban population was 61.7 percent in 1500, which increased to 67.8 percent in 1700 and 74 percent in 1800.
} 
(2012); Becker and Woessmann (2009); Cantoni (2012) and Rubin (2014)). ${ }^{8}$ These studies document a strong spatial dimension in the spread of Reformation and find that a region's distance to Wittenberg is a robust predictor of the adoption of Protestantism in the Holy Roman Empire. To explain this phenomenon, Cantoni (2012) argues that Reformation is a risky venture and the probability of success increases if more of the neighboring regions already adopted Protestantism, which creates positive spatial spillovers. Becker and Woessmann (2009) emphasize the frictions against the diffusion of information in the sixteenth century. Rubin (2014) provides empirical support for this hypothesis by showing that the presence of printing press was crucial in spreading Lutheran ideas and is a significant predictor of the adoption of Protestantism. One line of inquiry growing out of these findings is about the virtual absence of an economic rationale, hence a demand-side element, in the adoption and uneven geographic distribution of Protestantism. We complement existing studies by modeling the adoption of Protestantism as a rational choice of the regional rulers. The costly and risky decision of conversion brings about benefits by enabling the ruler to device more appropriate institutions, thereby increasing the regional output (i.e., tax base).

Our findings also complement Ekelund, Hébert, and Tollison (2002) who hypothesize an economic rationale for the reformation of a different nature. Their argument is that primogeniture created a wealthy land owning class that the old church could tax (by selling redemption through church intervenience and price discrimination through personal priest-client relationship) and bribed into the system (by offering church careers for younger sons). Their data confirm that regions across Europe with (effective) primogeniture typically stayed Catholic, in contrast to regions with partible inheritance rules and fragmented land ownership. They also explore the urban dimension and hypothesize that city growth means a changing wealth distribution which makes it more difficult for the Catholic Church to establish the personal

\footnotetext{
${ }^{8}$ In an interesting article, Iyigun (2008) documents a negative association between the Ottoman military advances in Europe and the number of military engagements between the Protestants and Counter-Reformation forces during the Reformation, which lends support for the hypothesis that the spread of Protestantism might have benefited from the wars against the Ottoman forces.
} 
priest-client relationship needed for price discrimination and rent extraction. Using our data we test explicitly for the link between city size (as an indicator for wealth) and reformation and find that it is the relatively poor cities that convert. ${ }^{9}$

The rest of the paper is organized as follows. Section 2 lays down the model which briefly presents the idea and derives the estimating equation. Section 3 discusses the data and the empirical methodology. Section 4 provides evidence for the positive (negative) relationship between agricultural potential (population) and the likelihood of conversion to Protestantism for the cities in the Holy Roman Empire during the Reformation and presents several robustness test. Section 5 concludes.

\section{Model}

We consider an overlapping-generations economy in discrete time. The model economy consists of $S$ different regions indexed by $s$ and each region has an urban core surrounded by a rural hinterland. ${ }^{10}$ These regions differ in their agricultural (rural) potential, $h_{s}$, arable land area, $Z_{s}$, and the appropriateness of prevailing institutions, $\lambda_{s}$, which determine the economic structure and population, $L_{s t}$, of the region. Goods market are segregated and labor is immobile across regions but perfectly mobile between urban and rural sectors within a region. ${ }^{11}$

\footnotetext{
${ }^{9}$ We also complement the study by Hopcroft (2003), who connects local rural field management institutions to productivity. While her analysis is explicit on institutional differences between North/Northwest, Central and East Germany in the early modern time, we can exploit detailed data on agricultural potential and realized productivity.

${ }^{10}$ We use interchangeably the terms "city" and "region" for this economic/political entity, as distinct from "territorium" which we investigate later in the empirical section and which is the legal entity that combines several cities-cum-hinterland.

${ }^{11}$ While the urban-rural distinction is not necessary for our hypothesis on the relationship between institutional appropriateness and the Reformation decision of the regional rulers, data on rural population are not available for the Holy Roman Empire in the 16th century. To show that urban population can be a good proxy for the total regional output and assess the impact of various mechanisms formally on our estimations, we opt to be explicit about the urban-rural structure of the economic units in the Holy Roman Empire.
} 


\section{$2.1 \quad$ Preferences}

Individuals live for two periods and each individual has a single parent. In the first period, individuals do not participate in the labor force and are supported by their parents. In the second period, they inelastically supply their labor and allocate their earnings between consumption and child rearing.

Parents, individuals born at time $t-1$, derive utility from consumption and the number of their children: ${ }^{12}$

$$
U\left(c_{t}^{u}, c_{t}^{r}, n_{t}\right)=\left(c_{t}^{u}\right)^{\theta}\left(c_{t}^{r}\right)^{\gamma} n_{t}^{1-\theta-\gamma}, \quad \theta, \gamma \in(0,1), \theta+\gamma<1
$$

where $c_{t}^{u}$ and $c_{t}^{r}$ denote the consumption levels of urban and rural goods, respectively. Urban and rural commodities are distinct in the sense that they satisfy different human needs. Naturally, one can consider the rural output as food and the urban output as other commodities produced specifically in the urban areas. $n_{t}$ is the number of children per person which is also equal to the crude birth rate. The budget constraint of the parent requires that total spending on consumption goods and child-raising does not exceed his income:

$$
p_{t}^{u} c_{t}^{u}+c_{t}^{r}+\rho n_{t} \leq y_{t}
$$

where $y_{t}$ is the per capita income, $p_{t}^{u}$ is the price of urban good and the agricultural good is the numéraire. Raising one child requires $\rho$ unit of the agricultural good.

\subsection{Production}

The rural sector produces goods using land and labor with constant returns to scale technology whereas the urban sector uses only labor. The rural and urban output produced at time $t$ in region $s, Y_{s t}^{r}$ and $Y_{s t}^{u}$ are given by:

$$
\begin{aligned}
& Y_{s t}^{r}=\lambda_{s}^{\alpha}\left(h_{s} Z_{s}\right)^{\alpha}\left(L_{s t}^{r}\right)^{1-\alpha}, \quad \alpha \in(0,1), \\
& Y_{s t}^{u}=\lambda_{s}^{\alpha} L_{s t}^{u},
\end{aligned}
$$

\footnotetext{
${ }^{12}$ Region subscripts are dropped whenever it does not lead to a confusion.
} 
where $\lambda_{s}$ reflects the appropriateness of institutions and $L_{s t}^{i}$ is the labor employed in area $i \in\{u, r\}$ in region $s$ at time $t .{ }^{13}$ The appropriateness of institutions differs from region to region reflecting the idea that the Catholic rule was not conducive enough for the emergence of the type of institutions compatible with the specificities of the local economic areas. Individuals earn the average output of the sector in which they are employed and choose the area to maximize their income. Since labor is fully mobile between urban and rural sectors within a region, wages are equalized, i.e. $Y_{s t}^{r} / L_{s t}^{r}=p_{s t}^{u} Y_{s t}^{u} / L_{s t}^{u}=y_{s t}$.

\subsection{Equilibrium}

Individuals maximize their utility (1) given the budget constraint (2). Cobb-Douglas preferences imply that individuals spend a constant fraction of their income on consumption goods and child-rearing:

$$
\begin{aligned}
c_{t}^{u} & =\theta \frac{y_{t}}{p_{t}^{u}}, \\
c_{t}^{r} & =\gamma y_{t}, \\
n_{t} & =(1-\theta-\gamma) \frac{y_{t}}{\rho} .
\end{aligned}
$$

Goods markets clear and workers earn the average value of output in the sector where they are employed. As a result, the split of employment over the rural and urban sectors is determined by the constant Cobb-Douglas expenditure shares and the share of rural employment is given by:

$$
\frac{L_{t}^{r}}{L_{t}}=1-\theta
$$

In order to characterize the evolution of the economy, we derive the law of motion for the working population which is the only state variable in our model. Since each individual has a single parent, the population level at time $t, L_{t}$, is given by the

\footnotetext{
${ }^{13}$ Notice that urban productivity is normalized to 1. As will be clear in Section 2.3, the level of productivity in the urban sector has no effect on the steady-state population level or urbanization rate.
} 
total number of children raised by the previous cohort:

$$
L_{t}=n_{t-1} L_{t-1}
$$

Using the equilibrium number of children (4), per capita income level $\left(y_{t-1}\right)$ from (3) and the urbanization rate (5) in (6), we obtain:

$$
L_{s t}=\Omega^{\alpha}\left(\lambda_{s} h_{s} Z_{s}\right)^{\alpha}\left(L_{s, t-1}\right)^{1-\alpha},
$$

where $\Omega=\left(\frac{1}{1-\theta}\right)\left(\frac{1-\theta-\gamma}{\rho}\right)^{1 / \alpha}$ is a constant which is the same across all regions. Expression (7) reveals that population ceases to grow in the long run since there are diminishing returns to the variable factor (labor) in the rural sector. The production function satisfies the Inada conditions, which guarantees that there is a unique steady-state with a positive level of population $\left(\bar{L}_{s}\right)$ given by:

$$
\bar{L}_{s}=\Omega \lambda_{s} h_{s} Z_{s}
$$

Now, we can find the steady-state value of total output as a function of agricultural potential, institutional appropriateness and arable land endowment. Using equation (8) and the fact that rural employment is a constant fraction of total workforce (5), we obtain that in the steady-state the total value of output, $\bar{Y}_{s}$, is a multiple of the total effective land endowment:

$$
\bar{Y}_{s}=\Phi \lambda_{s} h_{s} Z_{s}
$$

where $\Phi=\frac{1}{1-\theta}\left(\frac{1-\theta-\gamma}{\rho}\right)^{\frac{1-\alpha}{\alpha}}$. Consistent with the Malthusian logic and similar to Ashraf and Galor (2011), differences in agricultural potential or institutional appropriateness are reflected only in population densities, $\bar{L}_{s} / Z_{s}=\Omega \lambda_{s} h_{s}$, but not in per-capita income levels, $\bar{Y}_{s} / \bar{L}_{s}=\Phi / \Omega$, in the long-run.

\subsection{Reformation and the Ruler's Problem}

After Protestantism appeared as an alternative for the existing set of rules and institutional framework in the 16th century, the regional rulers faced a new decision 
which would have drastic consequences on the organization of the society. Investigating this transition in its multifaceted entirety is clearly beyond the scope of this paper. In the following, we perceive the adoption of Protestantism as an institutional change which possibly enhances regional sovereignty and concentration of power at the local level and creates opportunities to device institutions more compatible with regional necessities. We aim to determine its economic motives in a model of regime change where local authorities such as territorial lords or city councils maximize the tax base in the Malthusian context explained in the previous section. ${ }^{14}$

At time $T$ when the regional economies are at the long-run Malthusian equilibrium, the regional rulers are presented a new alternative governance structure. Now, they have the option to alter the institutional setting by converting to Protestantism. The change in the denomination has a probabilistic outcome on the institutional setting and the appropriateness of institutions. Conditional on the conversion decision the attempt is successful with probability $p$ and the appropriateness of institutions changes from $\lambda_{s}$ to $\bar{\lambda}$, otherwise it stays at the pre-Reformation level, $\lambda_{s}$. Adoption of Protestantism is costly and a fraction, $\mu$, of the regional output is foregone during conversion; hence, the cost of conversion is $C\left(\lambda_{s}, h_{s}, Z_{s}\right)=\mu \bar{Y}_{s}$ with $0<\mu<1$. $^{15}$

The ruler maximizes the present value of net regional output by deciding on whether to adopt protestantism or not. For simplicity, we assume that the regional ruler is motivated by the permanent improvements in the output and considers the

\footnotetext{
${ }^{14}$ While we generally refer to regional rulers as the decision maker in the text, the arguments are valid for all interest groups which internalize the economic costs and benefits of their political or denominational decisions at the regional level.

${ }^{15}$ Our results are not dependent on the assumption that conversion costs are a constant multiple of the regional output. Signs of the comparative statics with respect to the agricultural potential and population level are unaltered when we allow for a fixed cost component.
} 
post-Reformation steady-state income. ${ }^{16}$ Namely, his problem reads as:

$$
\begin{aligned}
\underset{R \in\{0,1\}}{\operatorname{maximize}} v\left(\lambda_{s}, h_{s}, Z_{s}\right) & =\Phi\left[\lambda_{s} h_{s} Z_{s}+\beta E\left[\tilde{\lambda}_{s} h_{s} Z_{s}\right]\right]-R C\left(\lambda_{s}, h_{s}, Z_{s}\right) \\
& =\Phi\left[(1+\beta) \lambda_{s} h_{s} Z_{s}+R p \beta\left(\bar{\lambda}-\lambda_{s}\right) h_{s} Z_{s}\right]-R C\left(\lambda_{s}, h_{s}, Z_{s}\right)
\end{aligned}
$$

where $R$ is the indicator function which takes the value of 1 when the ruler decides to convert, $\tilde{\lambda}$ is the post-Reformation level of institutional appropriateness which equals to $\bar{\lambda}$ in case of a successful transition and $\lambda_{s}$ otherwise, $\beta$ is the discount factor with $0<\beta<1$, and $E$ is the expectations operator. The ruler chooses to convert if the expected benefit of conversion exceeds the associated costs, namely if $p \beta \Phi\left(\bar{\lambda}-\lambda_{s}\right) h_{s} Z_{s}>C\left(\lambda_{s}, h_{s}, Z_{s}\right)=\mu \bar{Y}_{s}=\mu \Phi \lambda_{s} h_{s} Z_{s}$. Rearranging the last expression yields the cut-off level for the appropriateness of institutions, $\lambda^{*}$, below which all rulers adopt Protestantism whereas the regions with more appropriate institutions optimally prefer staying Catholic. In particular, the ruler decides to convert if

$$
\lambda_{s}<\lambda^{*} \equiv \frac{p \beta \bar{\lambda}}{\mu+p \beta}
$$

Equation (10) shows us that conversion is more likely when the expected increases in total output is large. ${ }^{17}$ This is the case when (i) the appropriateness of institutions before the Reformation is low, (ii) the probability of successful transition, $p$, is high or (iii) costs of Reformation, $\mu$, are low. ${ }^{18}$ While this expression might be useful to determine the regions which are more likely to convert, it is difficult to use it empirically since the appropriateness of institutions is not directly observable to

\footnotetext{
${ }^{16}$ All our qualitative results carry over to the setting in which the "dynastic ruler" takes the transition period and the associated cumulative benefits into account. The total gains during transition is a linear combination of the two steady states and the signs of the comparative statics with respect to the variables of interest are unaffected. Since this specification adds complexity to the problem without bringing in any additional insights, we prefer demonstrating our hypothesis in this simpler setting. The details are available upon request.

${ }^{17}$ We assume that $\lambda^{*}>\min \lambda_{s}$ with $s=1,2, \ldots, S$ to rule out the uninteresting case where no ruler has an incentive to convert. Note that $\bar{\lambda}>\lambda^{*}$ since $\mu>0$ which is apparent in (10).

${ }^{18}$ Cantoni (2012) explicitly focuses on the latter two determinants by propos ing that the military and economic risks associated with conversion are smaller when neighboring regions already adopted Protestantism.
} 
the researcher. To be able to express the cut-off condition using observable factors, we use the Malthusian structure of the economy to infer the appropriateness of institutions in terms of the agricultural potential and urban population level of a region. From (5) and (8), we obtain:

$$
\lambda_{s}=\frac{L_{s}^{u}}{\theta \Omega h_{s} Z_{s}} .
$$

Combining eq (11) with eq (10), we find that

$$
R= \begin{cases}1 & \text { if } \frac{L_{s}^{u}}{\theta \Omega h_{s} Z_{s}}<\frac{p \beta \bar{\lambda}}{\mu+p \beta} \\ 0 & \text { otherwise }\end{cases}
$$

Equation (12) summarizes the main argument in this paper. Given the urban population level $\left(L_{s}^{u}\right)$, higher agricultural potential $\left(h_{s}\right)$ signals worse institutions and untapped economic potential. Conversely, given the agricultural potential higher urban population implies a relatively well functioning economic system and more appropriate institutions. Hence, the demand for constitutional reform will be larger in the regions where the limits imposed by the Catholic governance on the institutional structure had severe effects, i.e. in the regions with higher agricultural potential and lower urban population. The rulers of these regions will have higher incentives for regime change and they were more likely to adopt the Reformation. Namely, when the exposure to 'treatment' is voluntary, the subjects with worse current situations but having higher potentials are more likely to receive the treatment. Hence, it is of crucial importance to control for the fundamental element which determines the potential of a subject, which turns out to be the agricultural potential in the context of Reformation, to assess the causal effect of the treatment.

\section{Data and Method}

\subsection{Empirical Specification}

We test the hypothesis that the cities which were smaller in economic terms but having higher agricultural potential were more likely to adopt Protestantism. In 
doing so, we estimate various linear probability models in the following form:

$$
\text { Protestant }_{i}=\beta_{0}+\beta_{1} \text { Agr Pot }_{i}+\beta_{2} \ln (\text { UrbPop })_{i}+\gamma \boldsymbol{X}_{\boldsymbol{i}}+\varepsilon_{i}
$$

where Protestant $_{i}$ is a binary variable and takes the value of one when city $i$ adopted Protestantism by 1600, Agr Pot ${ }_{i}$ denotes the agricultural potential in city $i, \ln (\operatorname{UrbPop})_{i}$ is the logged urban population of the city in $1500 . \gamma$ is a vector of coefficients and various control variables are stacked in vector $\boldsymbol{X}_{\boldsymbol{i}}$. Finally $\varepsilon_{i}$ is the error term which is assumed to be uncorrelated with any of the explanatory variables. In light of equation (12), we expect that the effect of agricultural potential is positive on the adoption of Protestantism whereas the (logged) population has a negative effect. We should note that there is no reliable data on the total arable land area of the regions in the Holy Roman Empire. Hence, we have to assume that it is not correlated with our measure of agricultural potential and the urban population.

\subsection{Main Variables}

We use the data on cities in the Holy Roman Empire from Cantoni (2012) and Bosker, Buringh, and van Zanden (2013) to empirically test our argument on the relationship between the appropriateness of institutions and the adoption of Protestantism. ${ }^{19}$ The dependent variable is the city's being Protestant by 1600 which comes from Cantoni (2012). It is a binary variable which takes the value of 1 if a church ordinance was drafted or introduced for the new Protestant state church by 1600. The 1600 division of cities is very similar to the one in 1648 after when the religious denominations of cities remained stable due to the Peace of Westphalia. Hence, the cities which are labeled as Protestant in our sample reflect permanent changes in religious denominations. One issue about using cities as the unit of analysis is that there are cases where more than one city fell under the same ruler; hence their religious statuses in 1600 were co-determined. Since we have data on

\footnotetext{
${ }^{19}$ We would like to thank Davide Cantoni and Maarten Bosker for sharing their data with us.
} 
agricultural potential only at the city level, it is natural to start the analysis from the city level. Clearly, this method assigns higher weights to the larger territories with more cities. We address this issue in two ways. First, we cluster the standard errors at the territory level. Second, we aggregate the variables which are available only at the city level by weighting them with the population shares of cities within their territory in 1500 and replicate our analysis at the territory level to test the robustness of the results. ${ }^{20}$

The main variable of interest is the agricultural potential which is compiled from Ramankutty, Foley, Norman, and McSweeney (2002). ${ }^{21}$ It measures the probability of the region's being cultivated based on its climatic suitability (growing degree days and moisture index) and soil quality (soil carbon density and soil pH in the top $30 \mathrm{~cm}$ of the soil) at a resolution of 0.5 degrees latitude-longitude (which on average corresponds to a grid of $55 \mathrm{~km}$ to $37 \mathrm{~km}$ in our sample). ${ }^{22}$ The advantage of using this measure is that it is based on biophysical, climatological or geographic attributes of a region and reflects the agricultural potential of the land rather than its actual utilization. Furthermore, it is plausibly exogenous to the conversion decision of the ruler and reverse causality does not seem to be an issue. However, in some cases, there are sizable differences in the agricultural potential of regions which are geographically close and possibly exposed to similar climatic conditions and have comparable levels of soil quality but are located in different grids. To avoid this type of noise, we smoothed the measure by computing the average of neighboring cells and use it as our baseline measure. ${ }^{23}$ In addition, we employ the ruggedness of

\footnotetext{
${ }^{20}$ The results are similar for different ways of aggregation such as assigning equal weights or using logged population in 1500 as the weight of each city. The qualitative results are unaffected in these estimations and the effect of agricultural potential becomes even larger. They are available upon request.

${ }^{21}$ This dataset has been used by many authors in different contexts. See e.g. Ashraf and Galor (2011), Ashraf and Galor (2013), Foley, Ramankutty, Brauman, Cassidy, Gerber, Johnston, Mueller, OConnell, Ray, West, et al. (2011) and Michalopoulos (2012)

${ }^{22}$ For details on the construction of the agricultural potential index and its discrepancy with actual land utilization, see Ramankutty, Foley, Norman, and McSweeney (2002).

${ }^{23}$ In an earlier version of the paper and unreported additional tests, we use different smoothing
} 
a region, which is defined as the standard deviation of the elevation of the terrain within $10 \mathrm{~km}$ from each city, as an inverse measure of the ease of cultivation. ${ }^{24} \mathrm{We}$ also use ruggedness as an instrument for the agricultural potential of a city after we show that ruggedness influences the probability of conversion only through its effect on the agricultural potential conditional on observables and present the results which are in line with the baseline findings in the appendix.

Urban population data comes from Bairoch, Batou, and Chèvre (1988) and is available at the city level. ${ }^{25}$ The population estimates of smaller cities is based on substantially less information and there is left censoring in Bairoch, Batou, and Chèvre (1988) where the population of the cities with less than 1000 inhabitants is recorded as missing. This is an important issue while testing the relationship between economic size and denominational choice since 128 of 249 cities in Cantoni (2012) have to be imputed. In the baseline analysis, we equate the population of the cities with missing population levels to 1000 as in Cantoni (2012) and exclude the small cities whose population did not reach 10.000 inhabitants at any point in time until 1800 in our baseline analysis. This restriction enables us to decrease the incidence of imputed population values substantially and focus on relatively large cities where conversion decision was less likely to be influenced by stronger regions and more determined by the local economic and institutional factors. We show the robustness of the main findings to the sampling choice and imputed population values in Section 4.2.4. The list of cities in our baseline sample is given in the appendix with their agricultural potential, urban population and distance to Wittenberg.

Clearly, urban population is at best an approximation for the total population schemes or the original point values to test the robustness of the baseline findings. The results are qualitatively identical and available upon request from the authors.

${ }^{24}$ Agricultural potential and terrain ruggedness are negatively correlated with a correlation coefficient of -0.437 .

${ }^{25}$ In unreported robustness tests which yield almost identical results with the baseline findings, we use Isenmann (2012) on the urban population of German and Austrian cities which generally implies an overestimation in Bairoch, Batou, and Chèvre (1988) for larger cities such as Augsburg, Nuernberg and Regensburg. 
of a city with its hinterland. While it is plausible that the economic prosperity of a region was reflected in its city size, this relationship might not hold for "parasite cities" where extra-economic forces are strong (see De Long and Shleifer (1993) for a discussion). To address this issue, we control for a city's having a university, being ecclesiastical and the per-capita number of monasteries which can also capture the relative size of the clergy and bureaucracy. In our model there is no cross-regional variation in urbanization rates due to homothetic Cobb-Douglas preferences (5). When there is non-homotheticity in preferences or the elasticity of substitution between rural and urban goods are different from 1, then urbanization rates might differ across regions due to productivity differences in the urban sector. Although our extensive set of control variables should capture a sizable share of the cross regional variation in urban productivity, we also use data on military war tax (Reichsmatrikel), which is a better measure than the urban population (Cantoni (2012)), to proxy for the economic and military size of a territory whenever it is available.

We include the age of the city and population growth rate between 1300 and 1500 to the specifications to control for the fact that some regions were not at the steady-state. In various specifications, we also control for the effects of various other factors which might influence the supply of and demand for Reformation and the adoption of Protestantism such as latitude, longitude, being close to a navigable river, distance to Wittenberg and the availability of printing press in 1500 . Table 1 presents the summary statistics for the variables used in our analysis. In the last column, we report the t-statistics of the tests where the null hypothesis is the equality of the group means.

It is seen that the regions which adopted Protestantism were smaller in city size, had higher agricultural potential and had less rugged terrain on average. We also present the spatial distribution of denominational choice and agricultural potential in Figures 1 and 2, respectively. Figure 1, where the circle size reflects the urban population of the city and the Catholic cities are underlined, reveals that there are two regions where denominational choice exhibits a significant degree of agglomera- 
Figure 1: Adoption of the Reformation and Urban Population

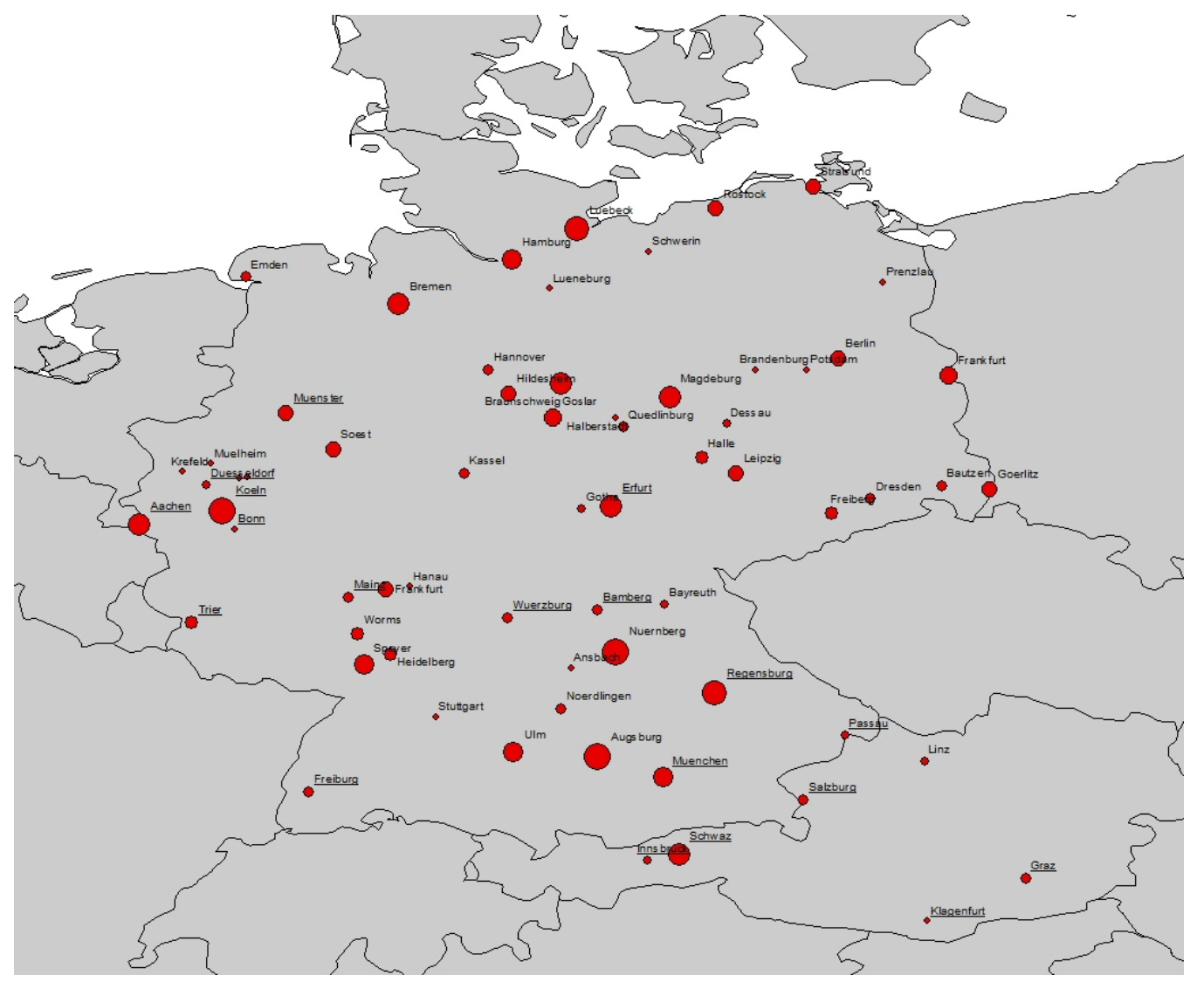

This map shows the diffusion of Reformation in the 16th century in our sample. The geographic area corresponds to present day Germany and Austria. Circle size reflects the urban population of the city in 1500. Catholic regions are underlined. 
Figure 2: Adoption of the Reformation and Agricultural Potential

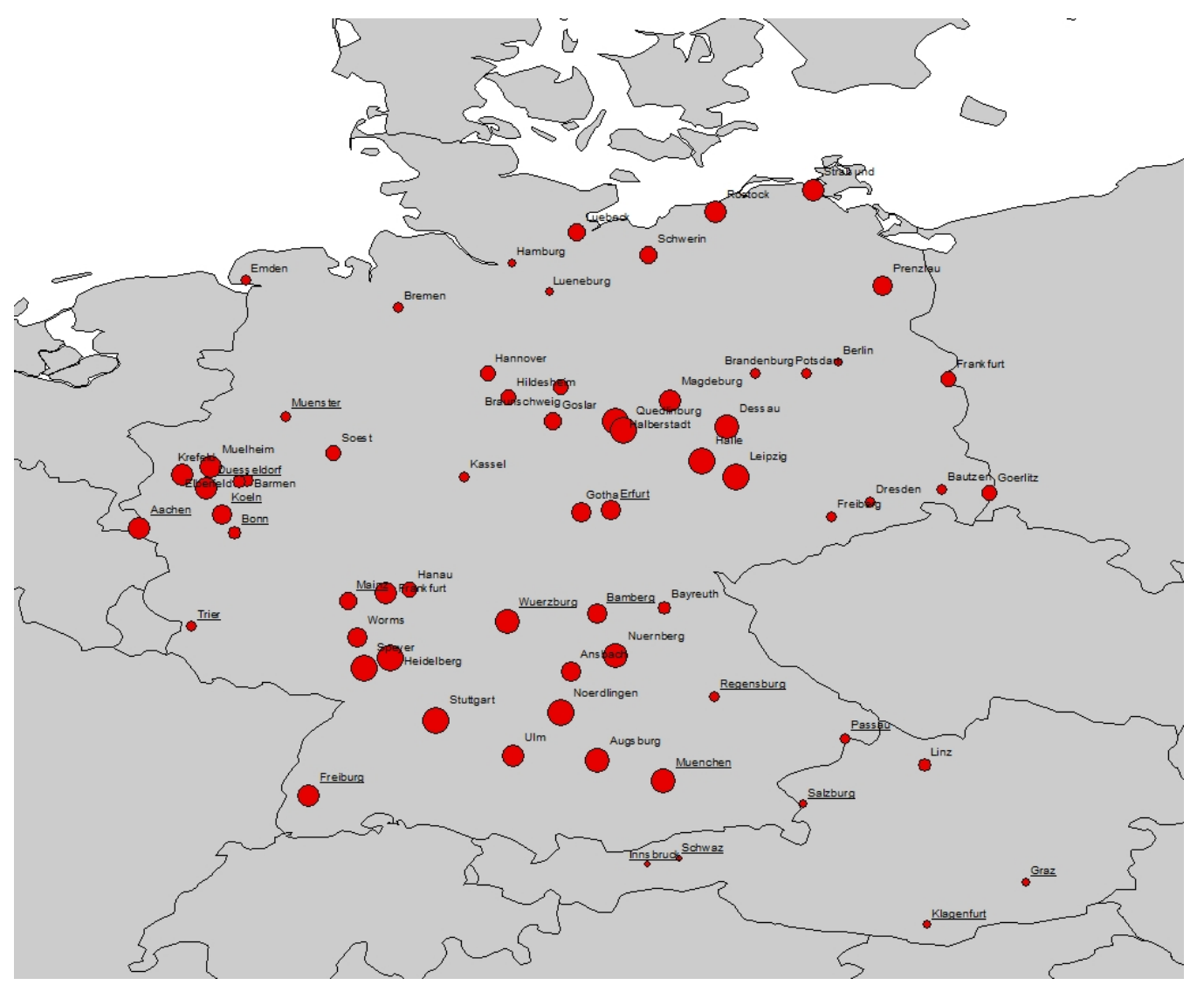

This map shows the distribution of agricultural potential variable used in our sample. The geographic area corresponds to present day Germany and Austria. Circle size reflects the agricultural potential of the city. Catholic regions are underlined. 
tion. While the cities lying North-east of the Muenster-Erfurt axis are all protestant, the cities in the south-east and Austria are mostly Catholic. In the following, we will examine the determinants of the adoption of Protestantism in a formal way. After presenting our baseline results in Section 4.1, we conduct a series of robustness tests to check the sensitivity of our results by investigating the presence of alternative explanations, relaxing the modeling assumptions, using different definitions of the political/geographic unit of analysis, employing different measures of agricultural potential, testing the presence of heterogeneous effects across sub-samples, assessing the role of the two agglomerations of denominational choice and controlling for the spatial correlation in the conversion decision of the local authorities in Section 4.2.

\section{Results}

\subsection{Main Results}

Table 2 presents the main results at the city level where having adopted Protestantism by 1600 is the dependent variable. Each column reports an estimation of equation (13) with a different set of controls including geographical, economical, institutional and informational factors with Column 5 showing our preferred specification.

It is seen that agricultural potential is an important determinant of conversion with a very significant and positive coefficient estimate. Furthermore, the (logged) population of the city in 1500 is negatively related to the likelihood of adopting Protestantism. Hence, our findings are consistent with the hypothesis that the probability of adopting Protestantism was significantly higher for the regions which had higher agricultural potential but could not materialize this advantage under the Catholic rule and were economically smaller. This pragmatic motive of religion choice is in line with our model but it has not been shown in the former studies investigating the diffusion of Protestantism.

This finding is robust to the control of various factors which are possibly related 
Table 1: Summary Statistics - City Level

\begin{tabular}{lccccc}
\hline \hline & & & \multicolumn{3}{c}{ Mean } \\
\cline { 4 - 5 } Variables & Mean & Std. Dev. & Catholic & Protestant & t-stat \\
\hline Protestant by 1600 & 0.71 & 0.46 & 0 & 1 & - \\
Agricultural Potential & 0.55 & 0.16 & 0.49 & 0.58 & -1.97 \\
Ruggedness & 57.12 & 95.62 & 113.88 & 34.17 & 2.18 \\
Latitude & 50.77 & 1.87 & 49.26 & 51.38 & -4.81 \\
Longitude & 10.58 & 2.43 & 10.11 & 10.76 & -0.88 \\
River & 0.52 & 0.5 & 0.47 & 0.53 & -0.42 \\
Population in 1500 (log) & 1.68 & 1.11 & 1.95 & 1.58 & 1.31 \\
Population growth 1300-1500 & 38.67 & 70.41 & 20.56 & 45.99 & -1.23 \\
City age & 6.68 & 3.9 & 8.59 & 5.91 & 2.16 \\
University & 0.12 & 0.33 & 0.26 & 0.06 & 1.81 \\
Ecclesiastical & 0.18 & 0.39 & 0.42 & 0.09 & 2.72 \\
Monasteries (p.c.) & 0.83 & 1.24 & 1.18 & 0.69 & 1.32 \\
Free Imperial City & 0.21 & 0.41 & 0.16 & 0.23 & -0.72 \\
Hanseatic & 0.21 & 0.42 & 0.11 & 0.26 & -1.55 \\
Distance to Wittenberg & 2.93 & 1.44 & 4.15 & 2.44 & 5.41 \\
Augustinian Monasteries & 0.27 & 0.45 & 0.47 & 0.19 & 2.15 \\
Printing Press & 0.26 & 0.44 & 0.32 & 0.23 & 0.65 \\
\hline \hline
\end{tabular}

This table presents the descriptive statistics for the main variables used in the empirical analysis at the city level. Columns 4 and 5 show the group means for Catholic and Protestant cities. Column 6 presents the test results on the equality of group means with unequal variances. 
to incentives of the rulers or the economic or geographic context which affected the likelihood of conversion. One robust determinant of the adoption of Protestantism is the closeness to or the presence of Catholic Church which are measured by the city's being ecclesiastical and the number of monasteries per capita, respectively. It is found that it was less likely for the ruler to convert in ecclesiastical cities where the legitimacy of the power was partly based on the clerical role of the regional ruler and/or in cities where the number of monasteries per capita was higher.

An interesting exercise is to compare the agricultural potential measure with the distance to Wittenberg which has been found to be the most important determinant of the spread of Protestantism in existing studies. It is seen that they perform equally well in terms of statistical significance or predictive power in city level regressions. Furthermore, the size of the estimate, albeit being smaller, is similar to that of the distance to Wittenberg. One standard deviation increase in agricultural potential increases the likelihood of adoption of Protestantism by 14.7 percentage points whereas one standard deviation increase in the distance to Wittenberg decreases the probability of adoption by 16.7 percentage points in our preferred specification (Column 6 of Table 2). Furthermore, one percent increase in the urban population of a city decreases the likelihood of drafting a new church ordinance by 0.10 percentage points. ${ }^{26}$ Figure 3 presents the effect of agricultural potential on the adoption of Protestantism conditional on the whole set of covariates used in Column 6 of Table 2 .

\subsection{Robustness Tests}

\subsubsection{An Alternative Explanation: Trade Potential}

In our model, we assume that goods markets are segregated and there is no trade. However, existence of trade might disrupt the Malthusian evolution of the economy

\footnotetext{
${ }^{26}$ In various specifications which are available upon request, we also control for a quadratic term in the distance to Wittenberg. It never affects the qualitative findings and increases the magnitude of the estimated effect of the agricultural potential in most cases.
} 
Table 2: Adoption of the Reformation

\begin{tabular}{|c|c|c|c|c|c|c|}
\hline & (1) & $(2)$ & $(3)$ & $(4)$ & $(5)$ & (6) \\
\hline Agricultural Potential & $\begin{array}{l}0.769^{*} \\
(0.397)\end{array}$ & $\begin{array}{l}0.828^{* *} \\
(0.380)\end{array}$ & $\begin{array}{c}0.837^{* * *} \\
(0.238)\end{array}$ & $\begin{array}{c}0.882^{* * *} \\
(0.259)\end{array}$ & $\begin{array}{c}1.011^{* * *} \\
(0.240)\end{array}$ & $\begin{array}{c}0.920^{* * *} \\
(0.257)\end{array}$ \\
\hline Population at $1500(\log )$ & & $\begin{array}{l}-0.075^{*} \\
(0.040)\end{array}$ & $\begin{array}{l}-0.068^{*} \\
(0.038)\end{array}$ & $\begin{array}{l}-0.060^{*} \\
(0.036)\end{array}$ & $\begin{array}{c}-0.123^{* *} \\
(0.053)\end{array}$ & $\begin{array}{c}-0.104^{* *} \\
(0.049)\end{array}$ \\
\hline Latitude & & & $\begin{array}{c}0.124^{* * *} \\
(0.022)\end{array}$ & $\begin{array}{c}0.123^{* * *} \\
(0.025)\end{array}$ & $\begin{array}{c}0.117^{* * *} \\
(0.025)\end{array}$ & $\begin{array}{c}0.040 \\
(0.036)\end{array}$ \\
\hline Longitude & & & $\begin{array}{l}0.040^{* *} \\
(0.017)\end{array}$ & $\begin{array}{c}0.028 \\
(0.018)\end{array}$ & $\begin{array}{c}0.004 \\
(0.018)\end{array}$ & $\begin{array}{c}-0.032^{*} \\
(0.017)\end{array}$ \\
\hline River & & & $\begin{array}{l}-0.033 \\
(0.101)\end{array}$ & $\begin{array}{c}0.004 \\
(0.100)\end{array}$ & $\begin{array}{c}0.071 \\
(0.089)\end{array}$ & $\begin{array}{c}0.096 \\
(0.090)\end{array}$ \\
\hline Population growth (1300-1500) & & & & $\begin{array}{l}0.001^{* *} \\
(0.001)\end{array}$ & $\begin{array}{c}0.001^{* * *} \\
(0.000)\end{array}$ & $\begin{array}{c}0.001 \\
(0.001)\end{array}$ \\
\hline City age & & & & $\begin{array}{l}-0.008 \\
(0.019)\end{array}$ & $\begin{array}{c}0.006 \\
(0.016)\end{array}$ & $\begin{array}{c}0.007 \\
(0.015)\end{array}$ \\
\hline University & & & & & $\begin{array}{c}-0.232 \\
(0.140)\end{array}$ & $\begin{array}{l}-0.176 \\
(0.145)\end{array}$ \\
\hline City ecclesiastical at 1500 & & & & & $\begin{array}{c}-0.324^{* *} \\
(0.127)\end{array}$ & $\begin{array}{c}-0.385^{* * *} \\
(0.131)\end{array}$ \\
\hline Monasteries per capita & & & & & $\begin{array}{c}-0.108^{* * *} \\
(0.027)\end{array}$ & $\begin{array}{c}* 0.102^{* * *} \\
(0.028)\end{array}$ \\
\hline Free Imperial city & & & & & $\begin{array}{c}0.040 \\
(0.156)\end{array}$ & $\begin{array}{c}0.033 \\
(0.127)\end{array}$ \\
\hline Hanseatic & & & & & $\begin{array}{c}0.057 \\
(0.130)\end{array}$ & $\begin{array}{c}0.081 \\
(0.119)\end{array}$ \\
\hline Distance to Wittenberg & & & & & & $\begin{array}{c}-0.116^{* * *} \\
(0.036)\end{array}$ \\
\hline Augustinian Monasteries & & & & & & $\begin{array}{l}-0.183 \\
(0.126)\end{array}$ \\
\hline Printing press by 1517 & & & & & & $\begin{array}{c}0.006 \\
(0.116)\end{array}$ \\
\hline Constant & $\begin{array}{c}0.286 \\
(0.262) \\
\end{array}$ & $\begin{array}{c}0.380 \\
(0.263) \\
\end{array}$ & $\begin{array}{c}-6.338^{* * *} \\
(1.110) \\
\end{array}$ & $\begin{array}{c}{ }^{*}-6.234^{* * *} \\
(1.434)\end{array}$ & $\begin{array}{c}* 5.596^{* * *} \\
(1.298) \\
\end{array}$ & $\begin{array}{c}-0.928 \\
(1.973) \\
\end{array}$ \\
\hline Observations & 66 & 66 & 66 & 66 & 66 & 66 \\
\hline$R^{2}$ & 0.069 & 0.102 & 0.387 & 0.440 & 0.626 & 0.673 \\
\hline
\end{tabular}

Dependent variable is a dummy variable which is 1 if there is a Protestant church ordinance drafted by 1600 . Robust standard errors are clustered at the territory level are in parenthesis. ${ }^{*} p<0.10,{ }^{* *} p<0.05,{ }^{* * *} p<0.01$ 
Figure 3: Adoption of the Reformation and Untapped Economic Potential
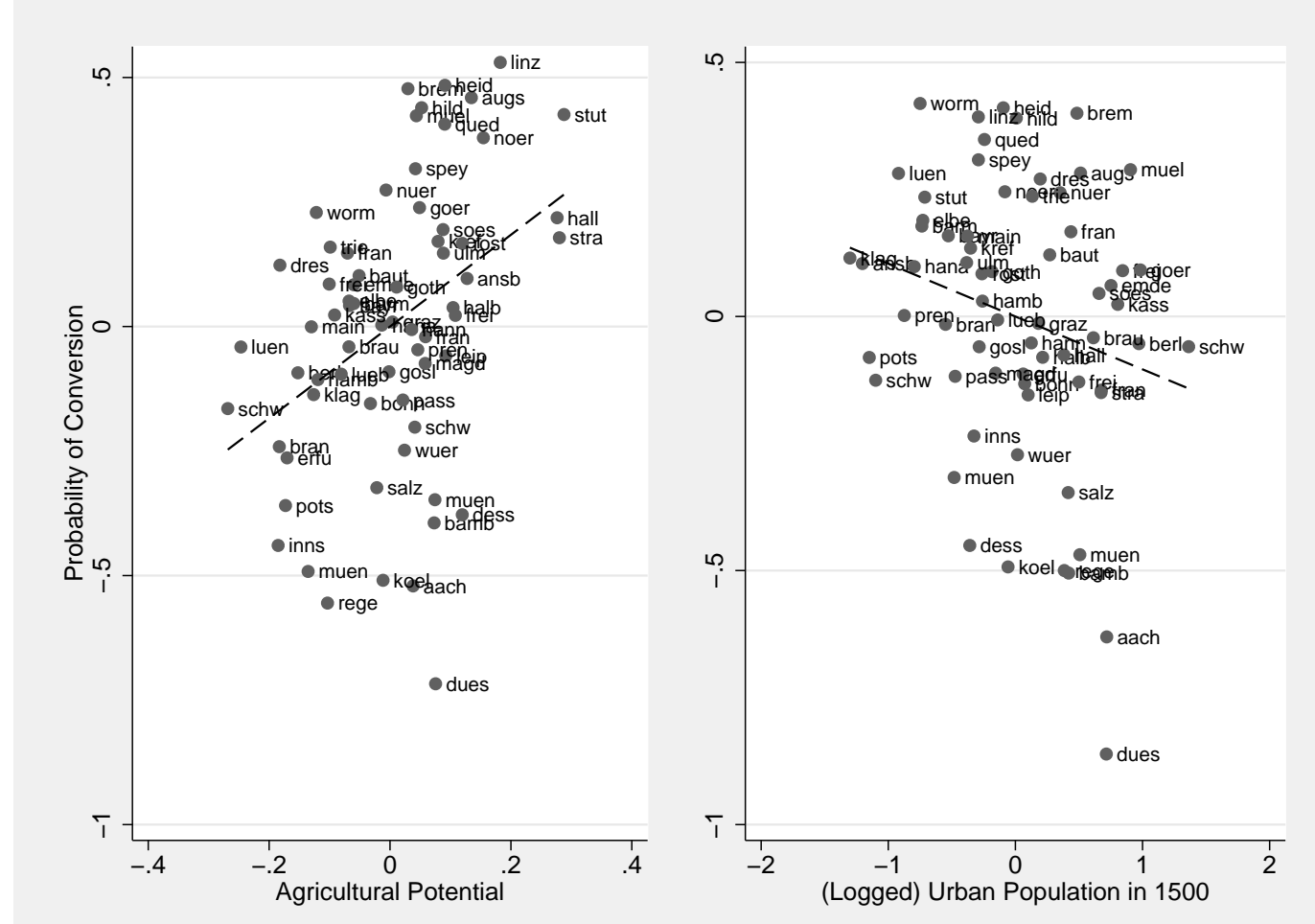

This figure shows the partial effect of agricultural potential and (logged) urban population on the probability of adopting the Reformation in the left and right panel, respectively.

in the first place since it can restrict the relative price of the agricultural good from above. In such a case, the effective land endowment will not be the only determinant of economic potential. Omitting trade leads to biased estimates if trade is correlated with agricultural potential and population, which is not unlikely. For instance, high agricultural potential and lower urban population may imply improper access to other markets and low potential for commerce. If trade constitutes an important component of economic potential and if it is negatively related to the adoption of Protestantism contrary to our hypothesis, then omitting trade potential would bias the estimates in favor of our argument.

While we control for the city's being close to a navigable river which might capture trade opportunities to some extent in our baseline specification, we investigate the effects of the trade potential further by using the urban potential of each city. Urban potential is used as a proxy for the trade potential of a city and comes from 
Bosker, Buringh, and van Zanden (2013). It measures the urban development in the proximity of each city and constructed based on Vries (1984) as follows:

$$
U P_{i}=\sum_{j \neq i}^{N} \frac{U r b P_{o p}}{D_{i j}}
$$

where $U P_{i}$ is the urban potential of city $i, D_{i j}$ is the great circle distance between city $i$ and $j$ and $N$ is the number of cities in the sample of Bosker, Buringh, and van Zanden (2013). We opted for this larger sample having information on 677 European cities since using only the cities in our sample would miss many relevant urban regions with possible trade linkages and lead to substantially under-estimated figures. ${ }^{27}$ Column 1 of Table 3 reports the specification which controls also for the urban potential and shows that our results are robust to this additional control. Furthermore, the urban potential variable is significant and positive with a sizable impact on the probability of conversion. One standard deviation increase in the urban potential increases the probability of conversion by 15.1 percentage points. This finding provides further support to our argument that the regions with higher economic potential with lower output were more likely to adopt Protestantism.

\subsubsection{An Alternative Measure for Agricultural Potential: Ruggedness}

One possible concern about our baseline estimations might be that the results are sensitive to the use of different proxies for agricultural potential. The proxy for agricultural potential is constructed based on the information about climatic conditions and soil quality. Although it is plausibly exogenous and not correlated to the unobservables which might influence the rulers' decision of conversion, one can argue that the organic carbon content of soil today, which is one of the factors determining soil quality, is affected by the intensity of historic land usage (see Vollrath (2010)) which might in turn be influenced by the adoption of the Reformation. To investi-

\footnotetext{
${ }^{27}$ The sample selection in Bosker, Buringh, and van Zanden (2013) is consistent with our choice, i.e. they consider the cities in Bairoch, Batou, and Chèvre (1988) and exclude the ones whose population did not reach 10.000 inhabitants at any point in time until 1800.
} 
gate the sensitivity of our baseline results to the choice of alternative measures of agricultural potential, we use the ruggedness of a region, which is exogenous to the land use, as an inverse measure for the ease of cultivation. Rugged terrain is difficult to cultivate since steep slopes increase the erosion hazard, the likelihood of landsliding and negatively affect the ease of water control (The Food and Agriculture Organization, 1993). ${ }^{28}$ The second column of Table 3 shows that the effect of terrain ruggedness on the adoption of the Reformation is negative, significant and robust to the control of various relevant factors affecting the adoption of Protestantism. Furthermore, in the estimations which are reported in the appendix it is seen that when agricultural potential is directly controlled for ruggedness is no longer significant which implies that the negative effect of terrain ruggedness operates through its contribution to agricultural potential conditional on observable factors. Given these findings, we also employ ruggedness as an instrument for the agricultural potential of a city. IV estimations which are presented in the third column of Table 3 are in line with the baseline findings and yield even larger coefficient estimates for the effect of agricultural potential on the likelihood of conversion. The first stage F-statistic is 38.02 indicating that ruggedness is a strong instrument for the baseline measure of agricultural potential. ${ }^{29}$

\subsubsection{Sub-samples and Heterogeneous Effects}

Another possible concern is that the effect of economic potential and the actual output might differ across different groups of regions. It arises possibly due to the fact that although Reformation marked a qualitative change in the relations among the Emperor, princes and local authorities, increasing regional autonomy and civic power had been an ongoing process which can be traced back long before the his-

\footnotetext{
${ }^{28}$ The economic effects of ruggedness have been investigated in a number of recent studies. For instance, Nunn and Puga (2012) show that ruggedness has a direct negative effect on the presentday per capita income while it has a differential positive impact in Africa since rugged terrain provided valuable protection against raids during slave trades.

${ }^{29}$ The first and second stage results replicating the specifications presented in Table 2 are reported in the Appendix.
} 
Table 3: Adoption of the Reformation - Robustness Tests I

\begin{tabular}{|c|c|c|c|c|c|c|}
\hline & $\begin{array}{c}\text { (1) } \\
\text { Trade } \\
\text { Potential }\end{array}$ & $\begin{array}{c}(2) \\
\text { Ruggedness }\end{array}$ & $\begin{array}{l}\text { (3) } \\
\text { IV }\end{array}$ & $\begin{array}{c}(4) \\
\text { Excl. } \\
\text { Ecclesiastical }\end{array}$ & $\begin{array}{c}(5) \\
\text { Excl. Free\& } \\
\text { Imperial }\end{array}$ & $\begin{array}{c}\quad(6) \\
\text { Excl. } \\
\text { Hanseatic }\end{array}$ \\
\hline Agricultural potential & $\begin{array}{c}0.924^{* * *} \\
(0.266)\end{array}$ & & $\begin{array}{c}1.181^{* * *} \\
(0.428)\end{array}$ & $\begin{array}{l}0.866^{* *} \\
(0.336)\end{array}$ & $\begin{array}{c}0.701^{* * *} \\
(0.226)\end{array}$ & $\begin{array}{c}0.940^{* * *} \\
(0.306)\end{array}$ \\
\hline Population at 1500 (log) & $\begin{array}{l}-0.084^{*} \\
(0.045)\end{array}$ & $\begin{array}{l}-0.077 \\
(0.048)\end{array}$ & $\begin{array}{l}-0.081^{*} \\
(0.043)\end{array}$ & $\begin{array}{l}-0.095^{*} \\
(0.051)\end{array}$ & $\begin{array}{l}-0.068 \\
(0.044)\end{array}$ & $\begin{array}{l}-0.104^{*} \\
(0.060)\end{array}$ \\
\hline Urban potential & $\begin{array}{l}0.502^{* *} \\
(0.216)\end{array}$ & $\begin{array}{l}0.532^{* *} \\
(0.237)\end{array}$ & $\begin{array}{c}0.504^{* * *} \\
(0.186)\end{array}$ & $\begin{array}{l}0.494^{* *} \\
(0.234)\end{array}$ & $\begin{array}{c}0.354 \\
(0.283)\end{array}$ & $\begin{array}{l}0.395^{*} \\
(0.204)\end{array}$ \\
\hline Ruggedness & & $\begin{array}{c}-0.001^{* *} \\
(0.000)\end{array}$ & & & & \\
\hline Latitude & $\begin{array}{l}0.086^{* *} \\
(0.042)\end{array}$ & $\begin{array}{c}0.068 \\
(0.043)\end{array}$ & $\begin{array}{c}0.087^{* *} \\
(0.038)\end{array}$ & $\begin{array}{c}0.059 \\
(0.040)\end{array}$ & $\begin{array}{l}0.098^{* *} \\
(0.042)\end{array}$ & $\begin{array}{c}0.074 \\
(0.049)\end{array}$ \\
\hline Longitude & $\begin{array}{c}0.011 \\
(0.026)\end{array}$ & $\begin{array}{c}0.002 \\
(0.025)\end{array}$ & $\begin{array}{c}0.015 \\
(0.024)\end{array}$ & $\begin{array}{c}0.012 \\
(0.028)\end{array}$ & $\begin{array}{c}0.002 \\
(0.031)\end{array}$ & $\begin{array}{c}0.009 \\
(0.027)\end{array}$ \\
\hline River & $\begin{array}{c}0.053 \\
(0.086)\end{array}$ & $\begin{array}{c}0.017 \\
(0.093)\end{array}$ & $\begin{array}{c}0.059 \\
(0.077)\end{array}$ & $\begin{array}{c}0.076 \\
(0.104)\end{array}$ & $\begin{array}{c}0.077 \\
(0.070)\end{array}$ & $\begin{array}{c}0.066 \\
(0.099)\end{array}$ \\
\hline Population growth (1300-1500) & $\begin{array}{c}0.001^{*} \\
(0.001)\end{array}$ & $\begin{array}{l}0.001^{*} \\
(0.001)\end{array}$ & $\begin{array}{l}0.001^{* *} \\
(0.001)\end{array}$ & $\begin{array}{c}0.001 \\
(0.001)\end{array}$ & $\begin{array}{l}0.001^{*} \\
(0.001)\end{array}$ & $\begin{array}{c}0.001 \\
(0.001)\end{array}$ \\
\hline City age & $\begin{array}{c}0.009 \\
(0.014)\end{array}$ & $\begin{array}{l}-0.001 \\
(0.017)\end{array}$ & $\begin{array}{c}0.011 \\
(0.012)\end{array}$ & $\begin{array}{c}0.005 \\
(0.015)\end{array}$ & $\begin{array}{c}0.016 \\
(0.017)\end{array}$ & $\begin{array}{c}0.009 \\
(0.015)\end{array}$ \\
\hline University & $\begin{array}{l}-0.178 \\
(0.128)\end{array}$ & $\begin{array}{l}-0.131 \\
(0.135)\end{array}$ & $\begin{array}{l}-0.182 \\
(0.115)\end{array}$ & $\begin{array}{l}-0.271^{*} \\
(0.146)\end{array}$ & $\begin{array}{l}-0.061 \\
(0.111)\end{array}$ & $\begin{array}{l}-0.069 \\
(0.170)\end{array}$ \\
\hline City ecclesiastical at 1500 & $\begin{array}{c}-0.376^{* * *} \\
(0.126)\end{array}$ & $\begin{array}{c}-0.371^{* *} \\
(0.151)\end{array}$ & $\begin{array}{c}-0.380^{* * *} \\
(0.107)\end{array}$ & $\begin{array}{c}0.000 \\
(.)\end{array}$ & $\begin{array}{c}-0.459^{* * *} \\
(0.107)\end{array}$ & $\begin{array}{c}-0.464^{* * *} \\
(0.139)\end{array}$ \\
\hline Monasteries per capita & $\begin{array}{c}-0.100^{* * *} \\
(0.032)\end{array}$ & $\begin{array}{c}-0.084^{* *} \\
(0.036)\end{array}$ & $\begin{array}{c}-0.104^{* * *} \\
(0.028)\end{array}$ & $\begin{array}{c}-0.065^{* *} \\
(0.029)\end{array}$ & $\begin{array}{c}-0.091^{* * *} \\
(0.028)\end{array}$ & $\begin{array}{c}-0.094^{* * *} \\
(0.031)\end{array}$ \\
\hline Free Imperial city & $\begin{array}{c}0.001 \\
(0.129)\end{array}$ & $\begin{array}{c}0.066 \\
(0.159)\end{array}$ & $\begin{array}{l}-0.029 \\
(0.129)\end{array}$ & $\begin{array}{c}0.038 \\
(0.140)\end{array}$ & $\begin{array}{c}0.000 \\
(.)\end{array}$ & $\begin{array}{c}0.109 \\
(0.216)\end{array}$ \\
\hline Hanseatic & $\begin{array}{c}0.149 \\
(0.125)\end{array}$ & $\begin{array}{c}0.098 \\
(0.128)\end{array}$ & $\begin{array}{c}0.172 \\
(0.118)\end{array}$ & $\begin{array}{c}0.120 \\
(0.124)\end{array}$ & $\begin{array}{l}0.265^{* *} \\
(0.101)\end{array}$ & $\begin{array}{c}0.000 \\
(.)\end{array}$ \\
\hline Distance to Wittenberg & $\begin{array}{c}-0.105^{* * *} \\
(0.038)\end{array}$ & $\begin{array}{c}-0.133^{* * *} \\
(0.034)\end{array}$ & $\begin{array}{c}-0.094^{* *} \\
(0.041)\end{array}$ & $\begin{array}{c}-0.122^{* * *} \\
(0.036)\end{array}$ & $\begin{array}{c}-0.107^{* *} \\
(0.041)\end{array}$ & $\begin{array}{c}-0.109^{* *} \\
(0.051)\end{array}$ \\
\hline Augustinian Monasteries & $\begin{array}{l}-0.167 \\
(0.126)\end{array}$ & $\begin{array}{l}-0.105 \\
(0.137)\end{array}$ & $\begin{array}{l}-0.185^{*} \\
(0.109)\end{array}$ & $\begin{array}{l}-0.253^{*} \\
(0.137)\end{array}$ & $\begin{array}{c}0.065 \\
(0.117)\end{array}$ & $\begin{array}{l}-0.153 \\
(0.145)\end{array}$ \\
\hline Printing press by 1517 & $\begin{array}{l}-0.055 \\
(0.107)\end{array}$ & $\begin{array}{l}-0.001 \\
(0.116)\end{array}$ & $\begin{array}{l}-0.085 \\
(0.101)\end{array}$ & $\begin{array}{c}0.086 \\
(0.131)\end{array}$ & $\begin{array}{c}-0.267^{* *} \\
(0.100)\end{array}$ & $\begin{array}{l}-0.012 \\
(0.151)\end{array}$ \\
\hline Constant & $\begin{array}{l}-4.479^{*} \\
(2.544)\end{array}$ & $\begin{array}{l}-2.805 \\
(2.636) \\
\end{array}$ & $\begin{array}{c}-4.745^{* *} \\
(2.313) \\
\end{array}$ & $\begin{array}{l}-2.991 \\
(2.396) \\
\end{array}$ & $\begin{array}{l}-4.757^{*} \\
(2.729) \\
\end{array}$ & $\begin{array}{l}-3.695 \\
(2.876) \\
\end{array}$ \\
\hline Observations & 66 & 66 & 66 & 54 & 52 & 52 \\
\hline$R^{2}$ & 0.698 & 0.652 & 0.693 & 0.672 & 0.786 & 0.720 \\
\hline
\end{tabular}

Dependent variable is a dummy variable which is 1 if there is a Protestant church ordinance drafted by 1600 . Robust standard errors are clustered at the territory level are in parenthesis. ${ }^{*} p<0.10,{ }^{* *} p<0.05,{ }^{* * *} p<0.01$ 
torical episode we investigate. This process created different institutional structures across regions, some of which might have been more suitable to limit the idiosyncratic tendencies of the regional rulers and influence the ruler's decision compatible with the specificities of the local economic area. In this case, the relationship between the adoption of Protestantism, economic potential and actual output would be stronger in the regions with initially high levels of regional autonomy and participative governance.

We consider this possibility in the last three columns of Table 3 where we report the estimated coefficients of relevant variables for cities with different institutional structures with the full set of controls presented in Column 6 of Table 2. Agricultural potential is always positive and significant and (logged) population is always negative, albeit being imprecisely estimated in some cases. Interestingly, once we exclude the Free and Imperial cities (Reichsstadt) the effect of agricultural potential is weaker, showing that the relationship between the appropriateness of institutions and the adoption of Protestantism is stronger among Free and Imperial cities. This finding is in line with the expectation that participatory governance limits the idiosyncratic tendencies of the regional rulers and makes the effect of economic fundamentals on the adoption of Protestantism more discernible. ${ }^{30}$

\subsubsection{Sampling Choice}

In the baseline estimations, we restrict our analysis to the cities whose population reached 10.000 inhabitants at any point in time until 1800. Smaller cities are excluded in our baseline estimations since it is likely that they were politically influenced by larger regions and the scope of self-determination of religious denomination

\footnotetext{
${ }^{30}$ This observation might also imply that the regions which responded more to economic incentives (with higher agricultural potential and lower population) had also been more likely to obtain the free city status before the Reformation. This is consistent with the argument that regional autonomy had been obtained through a protracted and sometimes conflictual process. To the extent that former improvements in the institutional structure provided only partial autonomy from the Emperor, the benefits of adopting Reformation were still large for Free and Imperial cities.
} 
was limited. Furthermore, estimates of population, which is one of the critical variables in our analysis, are noisy for smaller cities as recognized in the literature (Bairoch, Batou, and Chèvre (1988)). Left-censoring in the Bairoch dataset leads to missing population values for the majority of the smaller cities in 1500 . In this part, we show that the main findings are robust to the sampling choice.

First, we replicate our baseline analysis by excluding all cities with a missing population value in 1500 which decreases the sample size further to 54 cities. As seen in the first column of Table 4, the coefficient estimates for agricultural potential and population are significant with the expected signs and very similar to the baseline values.

Second, we use all cities which are included in Cantoni (2012) where population data is missing for 128 out of 249 cities and imputed to be 1000, and report the results in Column 2 of Table 4. As expected, population becomes insignificant due to the noise introduced by the imputation method while agricultural potential is still significant and appears with a positive sign.

Third, to show that the insignificance of population is indeed driven the imputation method and the postulated mechanism is valid also for smaller cities, we exclude the cities with imputed population values. The results, which are shown in Column 3 , are in line with the baseline estimations and (logged) population has a negative and significant effect on the probability of adopting Reformation.

\subsubsection{The Role of Agglomerations}

In Figure 1, we observe that there are two areas where the denominational choice shows significant degree of concentration: Northeast Germany where all cities adopted Reformation without exception and Austria where most of the regions stayed Catholic. If these agglomerations are also correlated with agricultural potential and population, then they might influence our baseline results. In such a case, understanding whether these agglomerations of denominational choice are driven by some omitted factors which are not controlled for in the empirical analysis would become important 
for the validity of our findings. In Figure 2, we present the values of agricultural potential on a similar map again together with the denominational choice of the cities, where the size of the circle reflects the agricultural potential of the city. While we do not observe a clear pattern in terms of agricultural potential for the North-eastern cities, Austrian cities are apparently not suitable for agriculture. Nevertheless, we address these issues explicitly by replicating our baseline analysis excluding these regions. In Table 4, the fourth column replicates the baseline specification excluding the cities lying Northeast of the Muenster-Erfurt axis. Although almost 45 percent of the observations are lost, the results are in line with the baseline findings. The coefficient estimate of agricultural potential is positive and significant. The (logged) population is negative and larger in magnitude than the baseline estimate. Similarly, the fifth column reports the results of the estimation where Austrian cities are excluded. Again agricultural potential and the population variables are significant with the expected signs. ${ }^{31}$ Hence our baseline results are not driven by the two agglomerations in the North East Germany or in Austria.

\subsubsection{Spatial Dependency}

An important issue in assessing the determinants of the adoption of Protestantism is the interactions among cities which are geographically close given the strong spatial dimension of the diffusion of the Reformation and the agglomeration patterns which we document in the preceding paragraphs. More importantly, Cantoni (2012) shows that strategic neighborhood interactions played a crucial role in the spread of the Reformation in the sense that conversion of the neighboring regions in previous periods had positive spillovers on the adoption decision of a particular city. It is also plausible that fertile lands are geographically clustered and agricultural potential of proximal cities are spatially correlated. Indeed the Moran's I statistic is positive and rejects the null hypothesis that there is zero spatial autocorrelation both for

\footnotetext{
${ }^{31}$ The results are robust to considering Munich, Regensburg and Passau also in the Catholic agglomeration in the South East.
} 
Table 4: Adoption of the Reformation - Robustness Tests II

\begin{tabular}{|c|c|c|c|c|c|}
\hline & $\begin{array}{c}(1) \\
\text { No Imputation } \\
\text { Baseline Sample }\end{array}$ & $\begin{array}{c}(2) \\
\text { Including Small } \\
\text { Cities }\end{array}$ & $\begin{array}{c}(3) \\
\text { Including Small } \\
\text { Cities-No Imp. }\end{array}$ & $\begin{array}{c}(4) \\
\text { Excluding } \\
\text { North-East }\end{array}$ & $\begin{array}{c}(5) \\
\text { Excluding } \\
\text { Austria }\end{array}$ \\
\hline Agricultural potential & $\begin{array}{c}0.938^{* * *} \\
(0.339)\end{array}$ & $\begin{array}{l}0.306^{* *} \\
(0.149)\end{array}$ & $\begin{array}{l}0.502^{* *} \\
(0.213)\end{array}$ & $\begin{array}{l}0.865^{* *} \\
(0.407)\end{array}$ & $\begin{array}{l}0.661^{* *} \\
(0.325)\end{array}$ \\
\hline Population at 1500 (log) & $\begin{array}{l}-0.127^{*} \\
(0.071)\end{array}$ & $\begin{array}{l}-0.028 \\
(0.032)\end{array}$ & $\begin{array}{c}-0.103^{* *} \\
(0.041)\end{array}$ & $\begin{array}{l}-0.205^{*} \\
(0.100)\end{array}$ & $\begin{array}{c}-0.113^{* *} \\
(0.056)\end{array}$ \\
\hline Latitude & $\begin{array}{c}0.058 \\
(0.058)\end{array}$ & $\begin{array}{l}0.060^{* *} \\
(0.027)\end{array}$ & $\begin{array}{l}0.055^{* *} \\
(0.026)\end{array}$ & $\begin{array}{l}-0.022 \\
(0.106)\end{array}$ & $\begin{array}{c}0.028 \\
(0.039)\end{array}$ \\
\hline Longitude & $\begin{array}{l}-0.029 \\
(0.023)\end{array}$ & $\begin{array}{l}-0.011 \\
(0.013)\end{array}$ & $\begin{array}{l}-0.004 \\
(0.013)\end{array}$ & $\begin{array}{l}-0.040 \\
(0.050)\end{array}$ & $\begin{array}{l}-0.022 \\
(0.030)\end{array}$ \\
\hline River & $\begin{array}{c}0.078 \\
(0.126)\end{array}$ & $\begin{array}{c}0.012 \\
(0.040)\end{array}$ & $\begin{array}{c}0.046 \\
(0.064)\end{array}$ & $\begin{array}{c}0.075 \\
(0.172)\end{array}$ & $\begin{array}{c}0.069 \\
(0.091)\end{array}$ \\
\hline Population growth (1300-1500) & $\begin{array}{c}0.001 \\
(0.001)\end{array}$ & $\begin{array}{c}0.000 \\
(0.001)\end{array}$ & $\begin{array}{l}-0.000 \\
(0.000)\end{array}$ & $\begin{array}{c}0.000 \\
(0.001)\end{array}$ & $\begin{array}{c}0.001 \\
(0.001)\end{array}$ \\
\hline City age & $\begin{array}{c}0.009 \\
(0.017)\end{array}$ & $\begin{array}{l}-0.000 \\
(0.015)\end{array}$ & $\begin{array}{l}-0.006 \\
(0.016)\end{array}$ & $\begin{array}{c}0.011 \\
(0.015)\end{array}$ & $\begin{array}{c}0.001 \\
(0.019)\end{array}$ \\
\hline University & $\begin{array}{l}-0.107 \\
(0.141)\end{array}$ & $\begin{array}{l}-0.173^{*} \\
(0.087)\end{array}$ & $\begin{array}{c}-0.217^{* *} \\
(0.107)\end{array}$ & $\begin{array}{c}0.132 \\
(0.264)\end{array}$ & $\begin{array}{l}-0.160 \\
(0.149)\end{array}$ \\
\hline City ecclesiastical at 1500 & $\begin{array}{l}-0.252 \\
(0.163)\end{array}$ & $\begin{array}{c}-0.528^{* * *} \\
(0.095)\end{array}$ & $\begin{array}{c}-0.235^{* *} \\
(0.115)\end{array}$ & $\begin{array}{c}-0.612^{* * *} \\
(0.192)\end{array}$ & $\begin{array}{c}-0.332^{* *} \\
(0.156)\end{array}$ \\
\hline Monastries per capita & $\begin{array}{c}-0.279^{* *} \\
(0.122)\end{array}$ & $\begin{array}{l}-0.024 \\
(0.019)\end{array}$ & $\begin{array}{c}-0.211^{* *} \\
(0.086)\end{array}$ & $\begin{array}{l}-0.088 \\
(0.054)\end{array}$ & $\begin{array}{c}-0.100^{* * *} \\
(0.030)\end{array}$ \\
\hline Free Imperial city & $\begin{array}{c}0.088 \\
(0.146)\end{array}$ & $\begin{array}{c}0.106 \\
(0.080)\end{array}$ & $\begin{array}{c}0.167^{*} \\
(0.096)\end{array}$ & $\begin{array}{c}0.178 \\
(0.286)\end{array}$ & $\begin{array}{c}0.061 \\
(0.123)\end{array}$ \\
\hline Hanseatic & $\begin{array}{l}-0.013 \\
(0.161)\end{array}$ & $\begin{array}{c}0.063 \\
(0.095)\end{array}$ & $\begin{array}{c}0.030 \\
(0.085)\end{array}$ & $\begin{array}{l}-0.151 \\
(0.390)\end{array}$ & $\begin{array}{c}0.101 \\
(0.127)\end{array}$ \\
\hline Distance to Wittenberg & $\begin{array}{l}-0.094^{*} \\
(0.055)\end{array}$ & $\begin{array}{c}-0.113^{* * *} \\
(0.029)\end{array}$ & $\begin{array}{c}-0.085^{* * *} \\
(0.024)\end{array}$ & $\begin{array}{c}-0.219^{*} \\
(0.118)\end{array}$ & $\begin{array}{c}-0.093^{* *} \\
(0.043)\end{array}$ \\
\hline Augustinian monastries & $\begin{array}{l}-0.195 \\
(0.133)\end{array}$ & $\begin{array}{c}0.023 \\
(0.066)\end{array}$ & $\begin{array}{c}0.018 \\
(0.068)\end{array}$ & $\begin{array}{c}-0.389^{* *} \\
(0.177)\end{array}$ & $\begin{array}{l}-0.175 \\
(0.130)\end{array}$ \\
\hline Printing press by 1517 & $\begin{array}{c}0.004 \\
(0.123)\end{array}$ & $\begin{array}{l}-0.116 \\
(0.112)\end{array}$ & $\begin{array}{l}-0.041 \\
(0.108)\end{array}$ & $\begin{array}{c}0.241 \\
(0.170)\end{array}$ & $\begin{array}{c}0.011 \\
(0.125)\end{array}$ \\
\hline Constant & $\begin{array}{l}-1.822 \\
(3.068) \\
\end{array}$ & $\begin{array}{l}-1.908 \\
(1.446) \\
\end{array}$ & $\begin{array}{l}-1.723 \\
(1.419) \\
\end{array}$ & $\begin{array}{c}2.780 \\
(6.037) \\
\end{array}$ & $\begin{array}{l}-0.249 \\
(2.007) \\
\end{array}$ \\
\hline $\begin{array}{l}\text { Observations } \\
R^{2}\end{array}$ & $\begin{array}{c}54 \\
0.693\end{array}$ & $\begin{array}{c}249 \\
0.529\end{array}$ & $\begin{array}{c}121 \\
0.574\end{array}$ & $\begin{array}{c}37 \\
0.743\end{array}$ & $\begin{array}{c}59 \\
0.606\end{array}$ \\
\hline
\end{tabular}

Dependent variable is a dummy variable which is 1 if there is a Protestant church ordinance drafted by 1600 . Robust standard errors are clustered at the territory level are in parenthesis. Column 1 excludes the cities with imputed population values for 1500 in the baseline sample, Column 2 presents the results for the full sample of cities which reached a population of 5000 by 1800 . Column 3 excludes cities with imputed population values which obtain a value of 1000 from the large sample. Column 4 and 5 show the results for the estimations by excluding the cities lying in the northeast of the Muenster-Erfurt axis and Austrian cities from the baseline sample, respectively. ${ }^{*} p<0.10,{ }^{* *} p<0.05,{ }^{* * *} p<0.01$ 
the dependent variable and the agricultural potential of a city. ${ }^{32}$ To control for the effects of spatial dependency inherent in our data on the baseline results and test whether the strategic neighborhood interactions emphasized by Cantoni (2012) are influential on our findings, we estimate spatial lag and spatial error models, where the former model controls for the spatial correlation in the dependent variable while the latter allows for spatial correlation due to unobservable factors. For the sake of brevity, the estimation results of the spatial error models, which are in line with the baseline results, are presented in the Appendix. Here, we discuss the estimation and the results of the spatial lag model which directly addresses the influence of the denominational choice of the neighboring regions. It is specified as follows:

$$
\boldsymbol{Y}=\boldsymbol{X} \beta+\rho \boldsymbol{W} \boldsymbol{Y}+\varepsilon
$$

where $\boldsymbol{Y}$ is an $N \mathrm{x} 1$ vector of observations on the denominational choice of the cities, $\boldsymbol{X}$ denotes an $N \times k$ matrix of observations on the explanatory variables including the agricultural potential and (logged) population of the cities, $\beta$ denotes a $k \times 1$ vector of parameters, $\boldsymbol{W}$ is an $N \times N$ spatial weights matrix, $\rho$ denotes the spatial autoregressive parameter and $\varepsilon$ is an $N \times 1$ vector of error terms which might exhibit arbitrary heteroscedasticity. $N$ and $k$ denote the number of cities and regression parameters in our sample, respectively. We specify the spatial weights matrix based on the inverse distances between cities and our results, which are shown in Table 5, are robust to different specifications of $\boldsymbol{W}$. These results are in line with the baseline findings and the coefficient estimates of the agricultural potential and (logged) population assume the expected signs and are very close to the main results. They also imply that the spatial interactions among cities are not particularly strong in our sample of cities conditional on the observed factors, which is consistent with our prior that excluding very small cities is essential in eliminating the confounding effects of neighboring stronger cities to isolate the local determinants of the adoption of the Reformation.

\footnotetext{
${ }^{32}$ Moran's I statistic of global spatial autocorrelation is 0.09 with a z-value of 4.817 for the adoption of Protestantism and 0.096 with a z-value of 5.151 for agricultural potential.
} 
Table 5: Adoption of the Reformation - Spatial Lag Model

\begin{tabular}{|c|c|c|c|c|c|c|}
\hline & $(1)$ & $(2)$ & $(2)$ & $(3)$ & $(4)$ & $(5)$ \\
\hline Agricultural potential & $\begin{array}{l}0.694^{* *} \\
(0.286)\end{array}$ & $\begin{array}{r}0.753^{* * *} \\
(0.277)\end{array}$ & $\begin{array}{c}0.825^{* * *} \\
(0.230)\end{array}$ & $\begin{array}{c}0.863^{* * *} \\
(0.233)\end{array}$ & $\begin{array}{c}0.977^{* * *} \\
(0.216)\end{array}$ & $\begin{array}{c}0.918^{* * *} \\
(0.219)\end{array}$ \\
\hline Population at 1500 (log) & & $\begin{array}{c}-0.076^{*} \\
(0.040)\end{array}$ & $\begin{array}{c}-0.068^{*} \\
(0.038)\end{array}$ & $\begin{array}{l}-0.061^{*} \\
(0.036)\end{array}$ & $\begin{array}{c}-0.117^{* *} \\
(0.052)\end{array}$ & $\begin{array}{c}-0.101^{* *} \\
(0.051)\end{array}$ \\
\hline Latitude & & & $\begin{array}{c}0.120^{* * *} \\
(0.029)\end{array}$ & $\begin{array}{c}0.118^{* * *} \\
(0.026)\end{array}$ & $\begin{array}{c}0.103^{* * *} \\
(0.021)\end{array}$ & $\begin{array}{c}0.038 \\
(0.030)\end{array}$ \\
\hline Longitude & & & $\begin{array}{c}0.039^{*} \\
(0.023)\end{array}$ & $\begin{array}{c}0.025 \\
(0.023)\end{array}$ & $\begin{array}{l}-0.003 \\
(0.021)\end{array}$ & $\begin{array}{l}-0.033^{*} \\
(0.017)\end{array}$ \\
\hline River & & & $\begin{array}{l}-0.033 \\
(0.094)\end{array}$ & $\begin{array}{c}0.003 \\
(0.090)\end{array}$ & $\begin{array}{c}0.071 \\
(0.079)\end{array}$ & $\begin{array}{c}0.095 \\
(0.078)\end{array}$ \\
\hline Population growth (1300-1500) & & & & $\begin{array}{l}0.001^{* *} \\
(0.001)\end{array}$ & $\begin{array}{c}0.001^{* * *} \\
(0.000)\end{array}$ & $\begin{array}{l}0.001^{*} \\
(0.000)\end{array}$ \\
\hline City age & & & & $\begin{array}{l}-0.008 \\
(0.016)\end{array}$ & $\begin{array}{c}0.008 \\
(0.014)\end{array}$ & $\begin{array}{c}0.007 \\
(0.014)\end{array}$ \\
\hline University & & & & & $\begin{array}{c}-0.247^{* *} \\
(0.124)\end{array}$ & $\begin{array}{l}-0.181 \\
(0.128)\end{array}$ \\
\hline City ecclesiastical at 1500 & & & & & $\begin{array}{c}-0.348^{* * *} \\
(0.122)\end{array}$ & $\begin{array}{c}{ }^{*}-0.392^{* * *} \\
(0.121)\end{array}$ \\
\hline Monasteries per capita & & & & & $\begin{array}{c}-0.104^{* * *} \\
(0.040)\end{array}$ & $\begin{array}{c}{ }^{*}-0.101^{* *} \\
(0.040)\end{array}$ \\
\hline Free Imperial city & & & & & $\begin{array}{c}0.019 \\
(0.136)\end{array}$ & $\begin{array}{c}0.026 \\
(0.113)\end{array}$ \\
\hline Hanseatic & & & & & $\begin{array}{c}0.059 \\
(0.118)\end{array}$ & $\begin{array}{c}0.079 \\
(0.113)\end{array}$ \\
\hline Distance to Wittenberg & & & & & & $\begin{array}{c}-0.110^{* * *} \\
(0.041)\end{array}$ \\
\hline Augustinian Monasteries & & & & & & $\begin{array}{l}-0.184^{*} \\
(0.109)\end{array}$ \\
\hline Printing press by 1517 & & & & & & $\begin{array}{c}0.004 \\
(0.103)\end{array}$ \\
\hline Constant & $\begin{array}{l}-0.245 \\
(0.229) \\
\end{array}$ & $\begin{array}{l}-0.157 \\
(0.235) \\
\end{array}$ & $\begin{array}{c}-6.209^{* * *} \\
(1.278) \\
\end{array}$ & $\begin{array}{c}-6.051^{* * *} \\
(1.263)\end{array}$ & $\begin{array}{c}*-5.144^{* * *} \\
(1.073) \\
\end{array}$ & $\begin{array}{c}-0.934 \\
(1.766) \\
\end{array}$ \\
\hline$\rho$ & $\begin{array}{c}0.779^{* * *} \\
(0.198)\end{array}$ & $\begin{array}{c}0.789^{* * *} \\
(0.189)\end{array}$ & $\begin{array}{c}0.116 \\
(0.537)\end{array}$ & $\begin{array}{c}0.180 \\
(0.502)\end{array}$ & $\begin{array}{c}0.447 \\
(0.402) \\
\end{array}$ & $\begin{array}{c}0.189 \\
(0.541)\end{array}$ \\
\hline Observations & 66 & 66 & 66 & 66 & 66 & 66 \\
\hline
\end{tabular}

This table presents the results of the estimation of the spatial lag model where the dependent variable is a dummy variable which is 1 if there is a Protestant church ordinance drafted by 1600. The spatial weights matrix is based on inverse distance and row-standardized. Robust standard errors clustered at the territory level are in parenthesis. ${ }^{*} p<0.10,{ }^{* *} p<0.05$, ${ }^{* * *} p<0.01$ 


\subsubsection{Choice of the Unit of Analysis: Territory Level Regressions}

The baseline analyses are conducted at the city level since the agricultural potential and the population variables are available at the city level. However, the conversion decisions were often taken by the territorial lords and the religious denominations of the cities falling under the same territorial ruler were co-determined. In the baseline estimations, the standard errors are clustered at the territory level to control for the correlation in the error terms between cities within a territory. In this part, we explicitly address this issue and investigate the validity of our hypothesis at the territory level. In doing so, we aggregate the variables of interest which are only available at the city level using the population share of cities within their territory. ${ }^{33}$ An additional advantage of using territory as the unit of analysis is that we have data on the military tax contribution of each territory (Reichsmatrikel) to proxy for the economic and military size of a region and the rulers' being an elector in determining the Emperor to control for an important factor in determining the demand for Reformation and regional sovereignty. Table 3 presents the results of the territory level estimations. It is seen that our baseline results are valid also at the territory level where agricultural potential is a positive and strong predictor of the adoption of Protestantism. Reichsmatrikel which is a proxy for the economic and military size of a territory is significant and negative. Remarkably, once we control for the co-determination of the religious status among the cities falling under the same territory, distance to Wittenberg becomes insignificant since the geographic coordinates of the territory explain much of the variation in the distance to Wittenberg for the smaller number of observations available at the territory level.

\section{Conclusion}

The idea that the birth of new institutions is at the heart of understanding development, long-term growth, and reversals of fortune is now widely shared among

\footnotetext{
${ }^{33}$ Using different weighting schemes does not alter the qualitative conclusions. The results are available upon request from the authors.
} 
Table 6: Adoption of the Reformation (Territories) - Robustness Tests III

\begin{tabular}{|c|c|c|c|c|c|}
\hline & (1) & $(2)$ & (3) & (4) & (5) \\
\hline \multirow[t]{2}{*}{ Agricultural potential } & $1.006^{* *}$ & $0.747^{*}$ & $1.074^{* *}$ & $1.011^{* *}$ & $0.815^{*}$ \\
\hline & $(0.449)$ & $(0.435)$ & $(0.415)$ & $(0.387)$ & $(0.463)$ \\
\hline \multirow[t]{2}{*}{ Population at 1500 (log) } & & -0.009 & -0.049 & -0.071 & -0.093 \\
\hline & & $(0.061)$ & $(0.059)$ & $(0.076)$ & $(0.091)$ \\
\hline \multirow[t]{2}{*}{ Reichsmatrikel } & & $-0.146^{* * *}$ & $-0.113^{*}$ & $-0.115^{*}$ & $-0.110^{*}$ \\
\hline & & $(0.053)$ & $(0.057)$ & $(0.060)$ & $(0.060)$ \\
\hline \multirow[t]{2}{*}{ Latitude } & & & $0.090^{* *}$ & $0.090^{* *}$ & 0.078 \\
\hline & & & $(0.039)$ & $(0.035)$ & $(0.049)$ \\
\hline \multirow[t]{2}{*}{ Longitude } & & & $0.060^{* *}$ & 0.058 & 0.051 \\
\hline & & & $(0.029)$ & $(0.035)$ & $(0.038)$ \\
\hline \multirow[t]{2}{*}{ River } & & & 0.094 & 0.120 & 0.121 \\
\hline & & & $(0.132)$ & $(0.112)$ & $(0.122)$ \\
\hline \multirow[t]{2}{*}{ University } & & & & -0.109 & -0.079 \\
\hline & & & & $(0.182)$ & $(0.196)$ \\
\hline \multirow[t]{2}{*}{ Elector } & & & & 0.203 & 0.165 \\
\hline & & & & $(0.142)$ & $(0.158)$ \\
\hline \multirow[t]{2}{*}{ City ecclesiastical at 1500} & & & & $-0.495^{* * *}$ & $-0.503^{* * *}$ \\
\hline & & & & $(0.158)$ & $(0.166)$ \\
\hline \multirow[t]{2}{*}{ Free Imperial city } & & & & 0.088 & 0.096 \\
\hline & & & & $(0.206)$ & $(0.204)$ \\
\hline \multirow[t]{2}{*}{ Distance to Wittenberg } & & & & & -0.038 \\
\hline & & & & & $(0.061)$ \\
\hline \multirow[t]{2}{*}{ Printing press by 1517} & & & & & 0.111 \\
\hline & & & & & $(0.147)$ \\
\hline \multirow[t]{2}{*}{ Constant } & 0.070 & 0.457 & $-4.914^{* *}$ & $-4.764^{* *}$ & -3.856 \\
\hline & $(0.289)$ & $(0.325)$ & $(1.990)$ & $(1.828)$ & $(2.857)$ \\
\hline Obser & 49 & 49 & 49 & 49 & 49 \\
\hline$R^{2}$ & 0.089 & 0.226 & 0.388 & 0.588 & 0.599 \\
\hline
\end{tabular}

Dependent variable is a dummy variable which is 1 if there is a Protestant church ordinance drafted by 1600 . Robust standard errors are clustered at the upper-territory level are in parenthesis. ${ }^{*} p<0.10,{ }^{* *} p<0.05,{ }^{* * *} p<0.01$ 
political scientists and economists. This calls for a quantification of the determinants of institutional change, which requires a setting in which a similar institutional change could happen across several regions. The German reformation provides the ideal case: Luthers theology, which appealed to all strata of society, all of a sudden provided the many local rulers in the Holy Roman Empire with the opportunity to remove the power of the church, strengthen their civil power, and realize the aspiration they had had for decades. The opportunity was, according to our findings, seized by those local rulers who had a relatively large potential to gain in economic terms from the change in institutions.

The German reformation, the shift in power to the regional authorities, and the process of state building that later grew out of this transition can thus be interpreted to be the result of a powerful combination: economic forces that created a need for institutional reform found themselves suddenly matched by a series of unique historical events around the person of Luther and the religious disputes and (mis)practices of the time that created the legitimation of institutional change.

Our finding documents an economic rationale of the adoption of Protestantism, which is absent in existing studies underscoring strategic neighborhood interactions (Cantoni (2012)) and diffusion of information (Becker and Woessmann (2009)). The results reveal an important source of positive selection into Reformation based on agricultural potential, which makes it crucial to control for the agricultural potential when investigating the Protestantism-Growth nexus during Industrialization (cf. Delacroix and Nielsen (2001); Becker and Woessmann (2009); Spenkuch (2011); and Cantoni (2014)). Identifying the effects of non-random selection into Reformation is an important topic for future research. ${ }^{34}$

\footnotetext{
${ }^{34}$ The interaction between agricultural potential, Protestantism and growth could go in several directions. On the one hand, growth and agricultural potential are potentially positively correlated. According to the labor push hypothesis, for example, higher agricultural productivity combined with Engel's law releases labor from stagnant agriculture to more dynamic economic activities and might lead to an earlier 'take-off' or higher growth rates (see, e.g., Alvarez-Cuadrado and Poschke (2011)). On the other hand, a negative link between growth and agricultural potential arises if comparative advantage in agriculture in an integrated market might restrict the labor flow out of
} 


\section{Appendix (Not for publication)}

Table 7 provides our data sources, which mainly come from Cantoni (2012) and Bosker, Buringh, and van Zanden (2013). Hence, for further details we refer the readers to these articles. Table 8 presents the religious denomination of the cities in our sample together with their agricultural potential and distance to Wittenberg. Table 9 replicates the baseline estimations where ruggedness is used as an inverse measure of the agricultural potential where column 7 corresponds to the column 2 of Table 3. Table 10 and 11 show the first and the second stages of the IV estimations where the agricultural potential is instrumented by the ruggedness of the city. Table 11 also includes the first stage diagnostics which show that the ruggedness of the city is a strong instrument for agricultural potential in all specifications. Table 12 provides the estimation results of the spatial error model which allows for spatial autocorrelation in the unobservables and is an alternative way of addressing the impact of spatial dependency on our findings. The spatial error model reads as follows:

$$
\boldsymbol{Y}=\boldsymbol{X} \beta+\lambda \boldsymbol{W} \psi+\varepsilon
$$

where $\boldsymbol{Y}$ denotes an $N \mathrm{x} 1$ vector of observations on the denominational choice of the cities, $\boldsymbol{X}$ denotes an $N$ x $k$ matrix of observations on the explanatory variables including the agricultural potential and (logged) population of the cities, $\beta$ denotes a $k \times 1$ vector of parameters, $\boldsymbol{W}$ is an $N \times N$ spatial weights matrix, $\lambda$ denotes the spatial autoregressive parameter, $\psi$ is an $N$ x 1 vector of spatial errors, $\varepsilon$ denotes an $N$ x 1 vector of error terms which might exhibit arbitrary heteroscedasticity. $N$ and $k$ denote the number of cities and regression parameters in our sample, respectively. We specify the spatial weights matrix based on the inverse distances between cities and our results, which are shown in Table 12, are robust to different specifications of $\boldsymbol{W}$. These results are in line with the baseline findings except that (logged) population is now significant at 10 percent in the most extended specification.

agriculture and leads to slower economic growth (see, e.g., Matsuyama (1992)). 
Finally, Table 13 presents the correlation matrix of the variables used in the analysis at the city level. 
Table 7: Data Sources

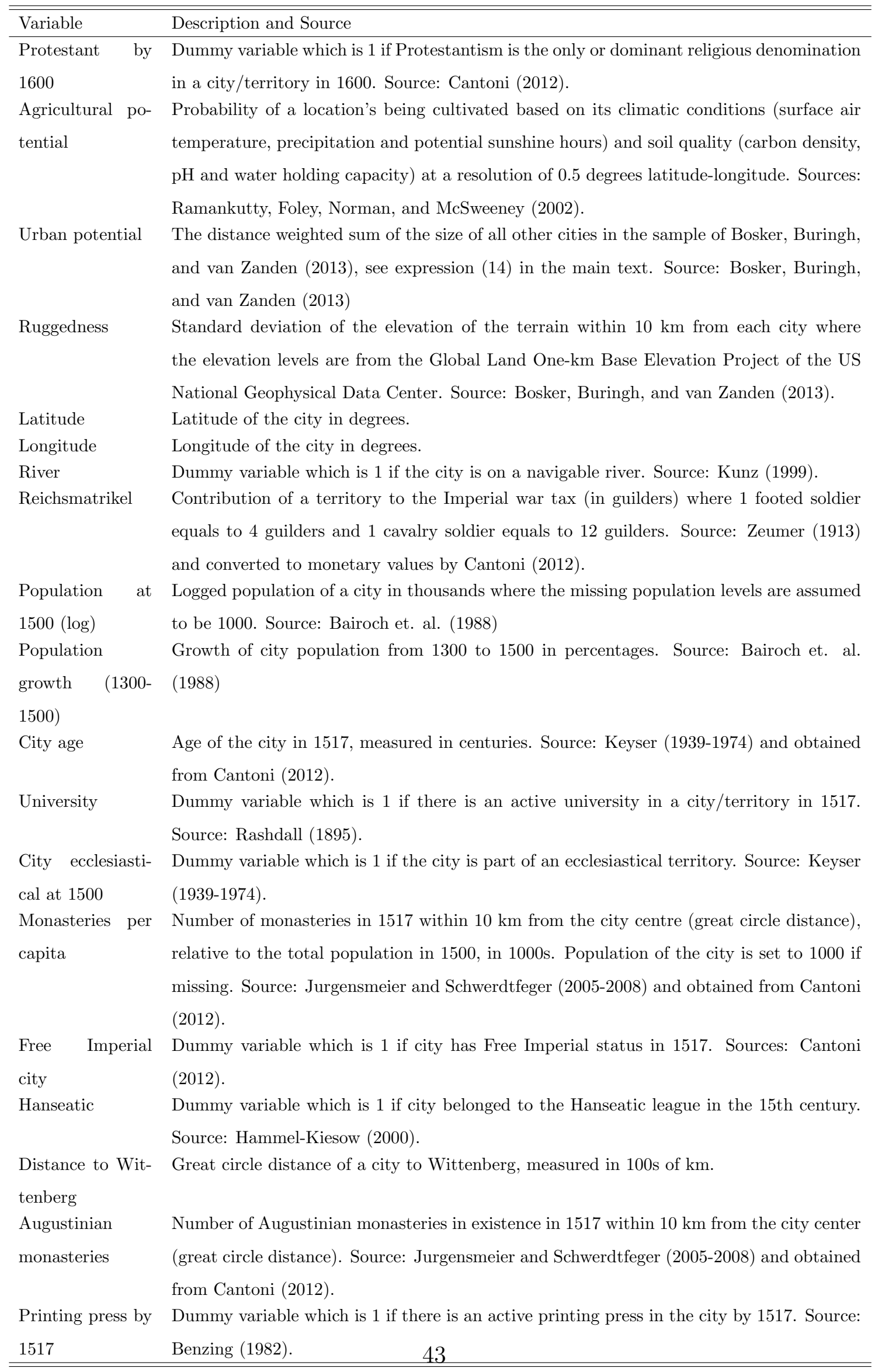


Table 8: List of Cities

\begin{tabular}{|c|c|c|c|c|}
\hline Cities & "Denomination & $\begin{array}{l}\text { Agricultural } \\
\text { Potential }\end{array}$ & $\begin{array}{c}\text { Distance to Wittenberg } \\
\text { (in } 100 \mathrm{kms} \text { ) }\end{array}$ & $\begin{array}{c}\text { Population in } \\
1500 \text { (in 1000s) }\end{array}$ \\
\hline Stuttgart & Protestant & 0.874 & 4.231 & 1 \\
\hline Halle & Protestant & 0.816 & 0.635 & 8 \\
\hline Heidelberg & Protestant & 0.796 & 3.884 & 8 \\
\hline Noerdlingen & Protestant & 0.768 & 3.682 & 6 \\
\hline Speyer & Protestant & 0.751 & 4.107 & 13 \\
\hline Quedlinburg & Protestant & 0.745 & 1.033 & 5 \\
\hline Halberstadt & Protestant & 0.745 & 1.087 & 1 \\
\hline Leipzig & Protestant & 0.744 & 0.649 & 10 \\
\hline Wuerzburg & Catholic & 0.733 & 2.984 & 7 \\
\hline Nuernberg & Protestant & 0.729 & 2.907 & 38 \\
\hline Augsburg & Protestant & 0.726 & 4.105 & 30 \\
\hline Dessau & Protestant & 0.715 & 0.288 & 2 \\
\hline Muenchen & Catholic & 0.711 & 4.220 & 13 \\
\hline Magdeburg & Protestant & 0.688 & 0.749 & 18 \\
\hline Freiburg & Catholic & 0.688 & 5.512 & 6 \\
\hline Frankfurt & Protestant & 0.680 & 1.397 & 11 \\
\hline Rostock & Protestant & 0.667 & 2.489 & 10 \\
\hline Ulm & Protestant & 0.664 & 4.289 & 16 \\
\hline Stralsund & Protestant & 0.664 & 2.741 & 11 \\
\hline Aachen & Catholic & 0.648 & 4.714 & 18 \\
\hline Muelheim & Protestant & 0.644 & 4.041 & 1 \\
\hline Duesseldorf & Catholic & 0.644 & 4.121 & 2 \\
\hline Krefeld & Protestant & 0.644 & 4.262 & 1 \\
\hline Gotha & Protestant & 0.625 & 1.683 & 3 \\
\hline Ansbach & Protestant & 0.623 & 3.214 & 1 \\
\hline Koeln & Catholic & 0.621 & 4.089 & 45 \\
\hline Worms & Protestant & 0.613 & 3.901 & 8 \\
\hline Bamberg & Catholic & 0.603 & 2.528 & 7 \\
\hline Prenzlau & Protestant & 0.597 & 1.808 & 1 \\
\hline Erfurt & Catholic & 0.595 & 1.510 & 19 \\
\hline Goslar & Protestant & 0.582 & 1.532 & 12 \\
\hline Schwerin & Protestant & 0.581 & 2.131 & 1 \\
\hline Luebeck & Protestant & 0.560 & 2.590 & 25 \\
\hline Mainz & Catholic & 0.558 & 3.693 & 6 \\
\hline Frankfurt & Protestant & 0.529 & 3.408 & 12 \\
\hline Hanau & Protestant & 0.529 & 3.243 & 1 \\
\hline Soest & Protestant & 0.525 & 3.138 & 10 \\
\hline Hannover & Protestant & 0.520 & 2.075 & 6 \\
\hline Hildesheim & Protestant & 0.520 & 1.873 & 10 \\
\hline Goerlitz & Protestant & 0.513 & 1.799 & 11 \\
\hline Braunschweig & Protestant & 0.511 & 1.529 & 18 \\
\hline Bonn & Catholic & 0.501 & 4.066 & 1 \\
\hline $\operatorname{Linz}$ & Protestant & 0.499 & 4.134 & 3 \\
\hline Barmen & Protestant & 0.495 & 3.807 & 1 \\
\hline Elberfeld & Protestant & 0.495 & 3.867 & 1 \\
\hline Bayreuth & Protestant & 0.482 & 2.257 & 2 \\
\hline Bautzen & Protestant & 0.453 & 1.477 & 5 \\
\hline Passau & Catholic & 0.452 & 3.694 & 4 \\
\hline Freiberg & Protestant & 0.449 & 1.174 & 8 \\
\hline Kassel & Protestant & 0.438 & 2.270 & 5 \\
\hline Regensburg & Catholic & 0.436 & 3.190 & 22 \\
\hline Muenster & Catholic & 0.436 & 3.451 & 10 \\
\hline Dresden & Protestant & 0.430 & 1.177 & 5 \\
\hline Bremen & Protestant & 0.425 & 2.935 & 18 \\
\hline Trier & Catholic & 0.416 & 4.833 & 8 \\
\hline Brandenburg & Protestant & 0.412 & 0.598 & 1 \\
\hline Emden & Protestant & 0.405 & 4.035 & 5 \\
\hline Potsdam & Protestant & 0.398 & 0.657 & 1 \\
\hline Berlin & Protestant & 0.374 & 0.885 & 9 \\
\hline Graz & Catholic & 0.370 & 5.664 & 5 \\
\hline Hamburg & Protestant & 0.367 & 2.592 & 15 \\
\hline Salzburg & Catholic & 0.308 & 4.416 & 7 \\
\hline Klagenfurt & Catholic & 0.267 & 5.941 & 1 \\
\hline Lueneburg & Protestant & 0.240 & 2.169 & 1 \\
\hline Innsbruck & Catholic & $0.174,14$ & 5.190 & 4 \\
\hline Schwaz & Catholic & $0.151^{44}$ & 5.080 & 17 \\
\hline
\end{tabular}


Table 9: Adoption of the Reformation - Ruggedness

\begin{tabular}{|c|c|c|c|c|c|c|c|}
\hline & $(1)$ & $(2)$ & $(3)$ & $(4)$ & $(5)$ & $(6)$ & $(7)$ \\
\hline \multirow[t]{2}{*}{ Ruggedness } & $-0.002^{* * *}$ & $-0.002^{* * *}$ & $-0.001^{*}$ & $-0.001^{* * *}$ & ${ }^{*}-0.001^{* * *}$ & $-0.001^{*}$ & -0.000 \\
\hline & $(0.000)$ & $(0.000)$ & $(0.000)$ & $(0.000)$ & $(0.000)$ & $(0.000)$ & $(0.000)$ \\
\hline \multirow[t]{2}{*}{ Agricultural potential } & & & & & & & $0.904^{* * *}$ \\
\hline & & & & & & & $(0.278)$ \\
\hline \multirow[t]{2}{*}{ Population at $1500(\log )$} & & -0.056 & -0.052 & -0.036 & $-0.098^{*}$ & $-0.100^{*}$ & $-0.102^{*}$ \\
\hline & & $(0.042)$ & $(0.042)$ & $(0.036)$ & $(0.055)$ & $(0.052)$ & $(0.054)$ \\
\hline \multirow[t]{2}{*}{ Latitude } & & & $0.107^{* * *}$ & $0.092^{* *}$ & $0.108^{* * *}$ & 0.021 & 0.038 \\
\hline & & & $(0.032)$ & $(0.037)$ & $(0.040)$ & $(0.036)$ & $(0.037)$ \\
\hline \multirow[t]{2}{*}{ Longitude } & & & $0.032^{*}$ & 0.015 & -0.003 & $-0.044^{* *}$ & $-0.032^{*}$ \\
\hline & & & $(0.017)$ & $(0.016)$ & $(0.020)$ & $(0.018)$ & $(0.017)$ \\
\hline \multirow[t]{2}{*}{ River } & & & -0.056 & -0.019 & 0.032 & 0.064 & 0.094 \\
\hline & & & $(0.110)$ & $(0.105)$ & $(0.101)$ & $(0.099)$ & $(0.091)$ \\
\hline \multirow[t]{2}{*}{ Population growth (1300-1500) } & & & & $0.001^{* *}$ & $0.001^{* *}$ & 0.001 & 0.001 \\
\hline & & & & $(0.001)$ & $(0.000)$ & $(0.001)$ & $(0.001)$ \\
\hline \multirow[t]{2}{*}{ City age } & & & & -0.016 & -0.006 & -0.003 & 0.006 \\
\hline & & & & $(0.021)$ & $(0.020)$ & $(0.018)$ & $(0.015)$ \\
\hline \multirow[t]{2}{*}{ University } & & & & & -0.121 & -0.133 & -0.172 \\
\hline & & & & & $(0.144)$ & $(0.151)$ & $(0.145)$ \\
\hline \multirow[t]{2}{*}{ City ecclesiastical at 1500} & & & & & $-0.293^{*}$ & $-0.379^{* *}$ & $-0.386^{* * *}$ \\
\hline & & & & & $(0.153)$ & $(0.155)$ & $(0.133)$ \\
\hline \multirow[t]{2}{*}{ Monasteries per capita } & & & & & $-0.091^{* * *}$ & $-0.086^{* * *}$ & $-0.101^{* * *}$ \\
\hline & & & & & $(0.034)$ & $(0.030)$ & $(0.028)$ \\
\hline \multirow[t]{2}{*}{ Free Imperial city } & & & & & 0.143 & 0.106 & 0.031 \\
\hline & & & & & $(0.171)$ & $(0.149)$ & $(0.132)$ \\
\hline \multirow[t]{2}{*}{ Hanseatic } & & & & & -0.048 & 0.023 & 0.083 \\
\hline & & & & & $(0.143)$ & $(0.127)$ & $(0.121)$ \\
\hline \multirow[t]{2}{*}{ Distance to Wittenberg } & & & & & & $-0.146^{* * *}$ & $-0.115^{* * *}$ \\
\hline & & & & & & $(0.037)$ & $(0.036)$ \\
\hline \multirow[t]{2}{*}{ Augustinian monasteries } & & & & & & -0.121 & -0.182 \\
\hline & & & & & & $(0.135)$ & $(0.128)$ \\
\hline \multirow[t]{2}{*}{ Printing press by 1517} & & & & & & 0.070 & 0.003 \\
\hline & & & & & & $(0.125)$ & $(0.120)$ \\
\hline \multirow[t]{2}{*}{ Constant } & $0.816^{* * *}$ & $0.908^{* * *}$ & $-4.899^{* * *}$ & $-3.920^{*}$ & $-4.398^{* *}$ & 0.821 & -0.812 \\
\hline & $(0.063)$ & $(0.079)$ & $(1.675)$ & $(2.019)$ & $(2.079)$ & $(2.011)$ & $(2.044)$ \\
\hline Observations & 66 & 66 & 66 & 66 & 66 & 66 & 66 \\
\hline$R^{2}$ & 0.145 & 0.163 & 0.332 & 0.400 & 0.560 & 0.624 & 0.673 \\
\hline
\end{tabular}

Dependent variable is a dummy variable which is 1 if there is a Protestant church ordinance drafted by 1600 . Robust standard errors are clustered at the territory level are in parenthesis. ${ }^{*} p<0.10,{ }^{* *} p<0.05,{ }^{* * *}$ $p<0.01$ 
Table 10: Adoption of the Reformation - IV 1. Stage

\begin{tabular}{|c|c|c|c|c|c|c|}
\hline & (1) & 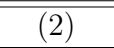 & (3) & $(4)$ & 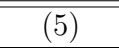 & (6) \\
\hline \multirow[t]{2}{*}{ Ruggedness } & $-0.001^{* * *}$ & $-0.001^{* * *}$ & $-0.001^{* * *}$ & $-0.001^{* * *}$ & $-0.001^{* * *}$ & $-0.001^{* * *}$ \\
\hline & $(0.000)$ & $(0.000)$ & $(0.000)$ & $(0.000)$ & $(0.000)$ & $(0.000)$ \\
\hline \multirow[t]{2}{*}{ Population at $1500(\log )$} & & 0.018 & 0.019 & 0.019 & 0.023 & 0.002 \\
\hline & & $(0.016)$ & $(0.015)$ & $(0.016)$ & $(0.026)$ & $(0.027)$ \\
\hline \multirow[t]{2}{*}{ Latitude } & & & -0.017 & -0.023 & -0.005 & -0.019 \\
\hline & & & $(0.012)$ & $(0.014)$ & $(0.018)$ & $(0.018)$ \\
\hline \multirow[t]{2}{*}{ Longitude } & & & -0.010 & $-0.011^{*}$ & -0.007 & -0.013 \\
\hline & & & $(0.007)$ & $(0.007)$ & $(0.009)$ & $(0.011)$ \\
\hline \multirow[t]{2}{*}{ River } & & & -0.023 & -0.018 & -0.037 & -0.033 \\
\hline & & & $(0.035)$ & $(0.037)$ & $(0.039)$ & $(0.038)$ \\
\hline \multirow[t]{2}{*}{ Population growth (1300-1500) } & & & & 0.000 & -0.000 & -0.000 \\
\hline & & & & $(0.000)$ & $(0.000)$ & $(0.000)$ \\
\hline \multirow[t]{2}{*}{ City age } & & & & -0.007 & $-0.012^{*}$ & $-0.010^{*}$ \\
\hline & & & & $(0.005)$ & $(0.006)$ & $(0.006)$ \\
\hline \multirow[t]{2}{*}{ University } & & & & $0.090^{* *}$ & $0.109^{* *}$ & 0.043 \\
\hline & & & & $(0.043)$ & $(0.049)$ & $(0.053)$ \\
\hline \multirow[t]{2}{*}{ City ecclesiastical at 1500} & & & & & 0.033 & 0.007 \\
\hline & & & & & $(0.057)$ & $(0.053)$ \\
\hline \multirow[t]{2}{*}{ Monasteries per capita } & & & & & 0.017 & 0.017 \\
\hline & & & & & $(0.016)$ & $(0.015)$ \\
\hline \multirow[t]{2}{*}{ Free Imperial city } & & & & & $0.111^{*}$ & 0.083 \\
\hline & & & & & $(0.060)$ & $(0.057)$ \\
\hline \multirow[t]{2}{*}{ Hanseatic } & & & & & $-0.110^{*}$ & -0.066 \\
\hline & & & & & $(0.064)$ & $(0.062)$ \\
\hline \multirow[t]{2}{*}{ Distance to Wittenberg } & & & & & & -0.034 \\
\hline & & & & & & $(0.024)$ \\
\hline \multirow[t]{2}{*}{ Augustinian Monasteries } & & & & & & 0.067 \\
\hline & & & & & & $(0.054)$ \\
\hline \multirow[t]{2}{*}{ Printing press by 1517} & & & & & & $0.075^{*}$ \\
\hline & & & & & & $(0.043)$ \\
\hline Adjusted $R^{2}$ & 0.178 & 0.182 & 0.206 & 0.221 & 0.258 & 0.331 \\
\hline Observations & 66 & 66 & 66 & 66 & 66 & 66 \\
\hline
\end{tabular}

This table presents the results of the first stage regression where the dependent variable is the agricultural potential and the excluded variable is the ruggedness of a city in the Holy Roman Empire. Robust standard errors clustered at the territory level are in parenthesis. * $p<0.10,{ }^{* *} p<0.05,{ }^{* * *} p<0.01$ 
Table 11: Adoption of the Reformation - IV 2. Stage

\begin{tabular}{|c|c|c|c|c|c|c|}
\hline & $(1)$ & $(2)$ & $(3)$ & $(4)$ & $(5)$ & $(6)$ \\
\hline Agricultural Potential & $\begin{array}{r}2.548^{* * *} \\
(0.535)\end{array}$ & $\begin{array}{l}2.474^{* * *} \\
(0.507)\end{array}$ & $\begin{array}{l}0.948^{* *} \\
(0.413)\end{array}$ & $\begin{array}{c}1.188^{* * *} \\
(0.303)\end{array}$ & $\begin{array}{c}1.164^{* * *} \\
(0.383)\end{array}$ & $\begin{array}{l}1.027^{* *} \\
(0.483)\end{array}$ \\
\hline Population at $1500(\log )$ & & $\begin{array}{c}-0.101^{* *} \\
(0.049)\end{array}$ & $\begin{array}{c}-0.070^{* *} \\
(0.034)\end{array}$ & $\begin{array}{l}-0.044 \\
(0.032)\end{array}$ & $\begin{array}{c}-0.125^{* * *} \\
(0.047)\end{array}$ & $\begin{array}{c}{ }^{*}-0.103^{* *} \\
(0.047)\end{array}$ \\
\hline Latitude & & & $\begin{array}{c}0.123^{* * *} \\
(0.022)\end{array}$ & $\begin{array}{c}0.118^{* * *} \\
(0.022)\end{array}$ & $\begin{array}{c}{ }^{*} 0.114^{* * *} \\
(0.027)\end{array}$ & $\begin{array}{c}0.041 \\
(0.032)\end{array}$ \\
\hline Longitude & & & $\begin{array}{c}0.042^{* * *} \\
(0.015)\end{array}$ & $\begin{array}{c}0.024 \\
(0.016)\end{array}$ & $\begin{array}{c}0.005 \\
(0.016)\end{array}$ & $\begin{array}{c}-0.030^{*} \\
(0.017)\end{array}$ \\
\hline River & & & $\begin{array}{l}-0.034 \\
(0.096)\end{array}$ & $\begin{array}{c}0.010 \\
(0.095)\end{array}$ & $\begin{array}{c}0.075 \\
(0.080)\end{array}$ & $\begin{array}{c}0.098 \\
(0.080)\end{array}$ \\
\hline Population growth (1300-1500) & & & & $\begin{array}{c}0.001^{* * *} \\
(0.000)\end{array}$ & $\begin{array}{c}{ }^{*} 0.001^{* * *} \\
(0.000)\end{array}$ & $\begin{array}{c}0.001 \\
(0.001)\end{array}$ \\
\hline City age & & & & $\begin{array}{l}-0.008 \\
(0.016)\end{array}$ & $\begin{array}{c}0.007 \\
(0.013)\end{array}$ & $\begin{array}{c}0.008 \\
(0.013)\end{array}$ \\
\hline University & & & & $\begin{array}{c}-0.323^{* *} \\
(0.130)\end{array}$ & $\begin{array}{l}-0.248^{*} \\
(0.135)\end{array}$ & $\begin{array}{c}-0.178 \\
(0.128)\end{array}$ \\
\hline City ecclesiastical at 1500 & & & & & $\begin{array}{c}-0.332^{* * *} \\
(0.114)\end{array}$ & $\begin{array}{c}-0.387^{* * *} \\
(0.113)\end{array}$ \\
\hline Monasteries per capita & & & & & $\begin{array}{c}-0.111^{* * *} \\
(0.023)\end{array}$ & $\begin{array}{c}* 0.104^{* * *} \\
(0.023)\end{array}$ \\
\hline Free Imperial city & & & & & $\begin{array}{c}0.015 \\
(0.161)\end{array}$ & $\begin{array}{c}0.021 \\
(0.131)\end{array}$ \\
\hline Hanseatic & & & & & $\begin{array}{c}0.079 \\
(0.137)\end{array}$ & $\begin{array}{c}0.091 \\
(0.116)\end{array}$ \\
\hline Distance to Wittenberg & & & & & & $\begin{array}{c}-0.111^{* * *} \\
(0.039)\end{array}$ \\
\hline Augustinian Monasteries & & & & & & $\begin{array}{c}-0.190^{*} \\
(0.111)\end{array}$ \\
\hline Printing press by 1517 & & & & & & $\begin{array}{c}-0.006 \\
(0.119)\end{array}$ \\
\hline F-Stat & 42.43 & 43.62 & 59.26 & 58.29 & 45.54 & 38.02 \\
\hline $\mathrm{AP} \chi^{2}$ & 43.99 & 45.94 & 65.54 & 67.86 & 57.02 & 50.46 \\
\hline Observations & 66 & 66 & 66 & 66 & 66 & 66 \\
\hline
\end{tabular}

This table presents the first stage diagnostics and the results of the second stage regression where the dependent variable is a dummy variable which is 1 if there is a Protestant church ordinance drafted by 1600 and the endogenous regressor, agricultural potential, is instrumented by ruggedness of the city. Robust standard errors clustered at the territory level are in parenthesis. First-stage diagnostics show that the instrument is strong in all specifications. ${ }^{*} p<0.10,{ }^{* *} p<0.05,{ }^{* * *} p<0.01$ 
Table 12: Adoption of the Reformation - Spatial Error Model

\begin{tabular}{|c|c|c|c|c|c|c|}
\hline & (1) & (2) & 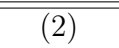 & (3) & 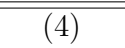 & (5) \\
\hline \multirow[t]{2}{*}{ Agricultural potential } & $0.739^{* *}$ & $0.820^{* * *}$ & $0.817^{* * *}$ & $0.853^{* * *}$ & $0.979^{* * *}$ & $0.920^{* * *}$ \\
\hline & $(0.317)$ & $(0.306)$ & $(0.235)$ & $(0.243)$ & $(0.244)$ & $(0.219)$ \\
\hline \multirow[t]{2}{*}{ Population at $1500(\log )$} & & $-0.078^{* *}$ & $-0.070^{*}$ & $-0.065^{*}$ & $-0.118^{* *}$ & $-0.105^{*}$ \\
\hline & & $(0.039)$ & $(0.038)$ & $(0.035)$ & $(0.054)$ & $(0.059)$ \\
\hline \multirow[t]{2}{*}{ Latitude } & & & $0.126^{* * *}$ & $0.129^{* * *}$ & $0.119^{* * *}$ & 0.040 \\
\hline & & & $(0.025)$ & $(0.025)$ & $(0.025)$ & $(0.040)$ \\
\hline \multirow[t]{2}{*}{ Longitude } & & & $0.039^{*}$ & 0.027 & 0.004 & $-0.032^{* *}$ \\
\hline & & & $(0.022)$ & $(0.022)$ & $(0.020)$ & $(0.015)$ \\
\hline \multirow[t]{2}{*}{ River } & & & -0.038 & -0.011 & 0.066 & 0.096 \\
\hline & & & $(0.097)$ & $(0.095)$ & $(0.084)$ & $(0.082)$ \\
\hline \multirow[t]{2}{*}{ Population growth (1300-1500) } & & & & $0.002^{* *}$ & $0.001^{* * *}$ & 0.001 \\
\hline & & & & $(0.001)$ & $(0.000)$ & $(0.001)$ \\
\hline \multirow[t]{2}{*}{ City age } & & & & -0.007 & 0.006 & 0.007 \\
\hline & & & & $(0.016)$ & $(0.014)$ & $(0.013)$ \\
\hline \multirow{2}{*}{ University } & & & & & $-0.232^{*}$ & -0.176 \\
\hline & & & & & $(0.120)$ & $(0.123)$ \\
\hline \multirow[t]{2}{*}{ City ecclesiastical at 1500} & & & & & $-0.333^{* * *}$ & $* 0.385^{* * *}$ \\
\hline & & & & & $(0.121)$ & $(0.121)$ \\
\hline \multirow{2}{*}{ Monasteries per capita } & & & & & $-0.100^{* *}$ & $-0.102^{* *}$ \\
\hline & & & & & $(0.044)$ & $(0.048)$ \\
\hline \multirow[t]{2}{*}{ Free Imperial city } & & & & & 0.031 & 0.034 \\
\hline & & & & & $(0.136)$ & $(0.114)$ \\
\hline \multirow[t]{2}{*}{ Hanseatic } & & & & & 0.053 & 0.082 \\
\hline & & & & & $(0.127)$ & $(0.125)$ \\
\hline \multirow[t]{2}{*}{ Distance to Wittenberg } & & & & & & $-0.116^{* * *}$ \\
\hline & & & & & & $(0.040)$ \\
\hline \multirow[t]{2}{*}{ Augustinian Monasteries } & & & & & & $-0.183^{*}$ \\
\hline & & & & & & $(0.110)$ \\
\hline \multirow[t]{2}{*}{ Printing press by 1517} & & & & & & 0.007 \\
\hline & & & & & & $(0.123)$ \\
\hline \multirow[t]{2}{*}{ Constant } & 0.251 & 0.345 & $-6.417^{* * *}$ & $-6.475^{* * *}$ & $-5.672^{* * *}$ & -0.906 \\
\hline & $(0.294)$ & $(0.295)$ & $(1.194)$ & $(1.280)$ & $(1.218)$ & $(2.216)$ \\
\hline \multicolumn{7}{|c|}{, (2 } \\
\hline & $0.776^{* * *}$ & $0.788^{* * *}$ & 0.246 & 0.409 & 0.282 & -0.026 \\
\hline & $(0.199)$ & $(0.187)$ & $(0.538)$ & $(0.467)$ & $(0.602)$ & $(0.999)$ \\
\hline Observations & 66 & 66 & 66 & 66 & 66 & 66 \\
\hline
\end{tabular}

This table presents the results of the estimation of the spatial error model where the dependent variable is a dummy variable which is 1 if there is a Protestant church ordinance drafted by 1600 . The spatial weights matrix is based on inverse distance and row-standardized. Robust standard errors clustered at the territory level are in parenthesis. ${ }^{*} p<0.10,{ }^{* *}$ $p<0.05,{ }^{* * *} p<0.01$ 


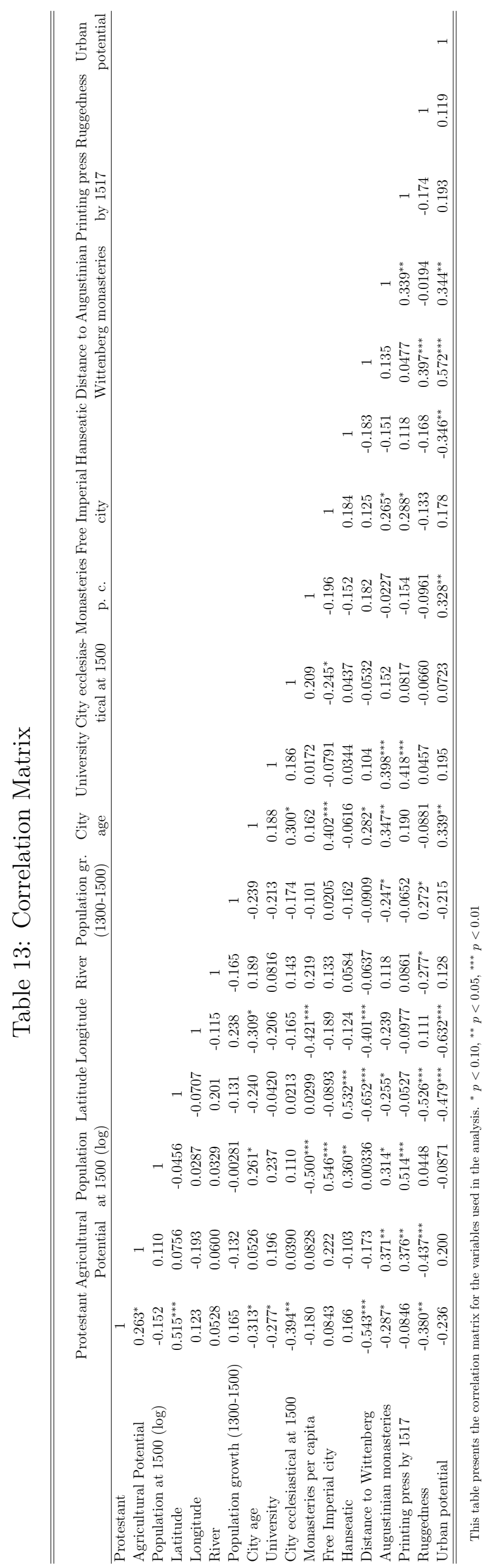




\section{References}

Acemoglu, D., S. Johnson, And J. Robinson (2005): "The rise of Europe: Atlantic trade, institutional change, and economic growth," American economic review, pp. 546-579.

Alvarez-Cuadrado, F., And M. Poschke (2011): "Structural change out of agriculture: Labor push versus labor pull," American Economic Journal: Macroeconomics, 3(3), 127-158.

ArruñadA, B. (2010): "Protestants and Catholics: Similar Work Ethic, Different Social Ethic," The Economic Journal, 120(547), 890-918.

Ashraf, Q., And O. Galor (2011): "Dynamics and Stagnation in the Malthusian Epoch," American Economic Review, 101, 2003-2041.

(2013): "The out of Africa hypothesis, human genetic diversity, and comparative economic development," The American Economic Review, 103(1), 1-46.

Bairoch, P., J. Batou, And P. Chèvre (1988): Population des villes européennes de 800 à 1850: banque de données et analyse sommaire des résultats (la). Librairie Droz.

Becker, S. O., S. Pfaff, and J. Rubin (forthcoming): "Causes and Consequences of the Protestant Reformation," Explorations in Economic History.

Becker, S. O., And L. Woessmann (2009): "Was Weber wrong? A human capital theory of Protestant economic history," The Quarterly Journal of Economics, $124(2), 531-596$.

Benzing, J. (1982): Die Buchdrucker des 16. und 17. Jahrhunderts im deutschen Sprachgebiet, vol. 2. O. Harrassowitz.

Bergsma, W., and E. Waterbolk (1986): Kroniekje van een Ommelander boer in de zestiende eeuw. Wolters-Noordhoff/Forsten. 
Berkowitz, D., K. Pistor, and J.-F. Richard (2003): "Economic development, legality, and the transplant effect," European Economic Review, 47(1), $165-195$.

Berman, H. J. (2009): Law and Revolution, II: The Impact of the Protestant Reformations on the Western Legal Tradition. Harvard University Press.

Besley, T., and T. Persson (2009): "The Origins of State Capacity: Property Rights, Taxation, and Politics," American Economic Review, 99(4), 1218-44.

Blum, U., And L. Dudley (2001): "Religion and economic growth: was Weber right?," Journal of Evolutionary Economics, 11(2), 207-230.

Bonney, R. (1991): The European dynastic states, 1494-1660. Oxford University Press Oxford.

Bosker, M., E. Buringh, and J. L. van Zanden (2013): "From Baghdad to London: Unraveling Urban Development in Europe, the Middle East, and North Africa, 800-1800," Review of Economics and Statistics, 95(4), 1418-1437.

Brady, T. A. (2007): "Emergence and consolidation of Protestantism in the Holy Roman Empire to 1600," The Cambridge History of Christianity, 6, 20-36.

BREnNeR, R. (1993): Merchants and revolution: commercial change, political conflict, and London's overseas traders, 1550-1653. Cambridge [etc.]: Cambridge University Press.

Cantoni, D. (2012): "Adopting a New Religion: the Case of Protestantism in 16th Century Germany," The Economic Journal, 122(560), 502-531.

(2014): "The economic effects of the Protestant Reformation: testing the Weber hypothesis in the German Lands," Journal of the European Economic Association, p. to appear.

Capoccia, G., and R. D. Kelemen (2007): "The study of critical junctures: Theory, narrative, and counterfactuals in historical institutionalism," World Politics, 59(03), 341-369. 
De Long, J. B., And A. Shleifer (1993): "Princes and merchants: European city growth before the industrial revolution," Journal of law and economics, 36(2), $671-702$.

Delacroix, J., And F. Nielsen (2001): "The beloved myth: Protestantism and the rise of industrial capitalism in nineteenth-century Europe," Social Forces, 80(2), 509-553.

Ekelund, R. B., R. F. HÉBert, and R. D. Tollison (2002): "An economic analysis of the protestant reformation," Journal of Political Economy, 110(3), 646-671.

Foley, J. A., N. Ramankutty, K. A. Brauman, E. S. Cassidy, J. S. GerBer, M. Johnston, N. D. Mueller, C. OConnell, D. K. Ray, P. C. West, ET AL. (2011): "Solutions for a cultivated planet," Nature, 478(7369), $337-342$.

Greif, A., AND D. D. LAitin (2004): "A theory of endogenous institutional change," American Political Science Review, 98(04), 633-652.

Greif, A., And J. Rubin (2014): "Endogenous Political Legitimacy: The English Reformation and the Institutional Foundation of Limited Government," https://bfi.uchicago.edu/research/working-paper/endogenous-politicallegitimacy-english-reformation-and-institutional.

Hammel-Kiesow, R. (2000): Die Hanse, vol. 2131. CH Beck.

Hill, C. (1961): "Protestantism and the Rise of Capitalism," Essays in the Economic and Social History of Tudor and Stuart England: in Honour of RH Tawney, pp. 15-39.

Hopcroft, R. L. (2003): "Local Institutions and Rural Development in European History," Social Science History, 27(1), 25-74.

Isenmann, E. (2012): Die deutsche Stadt im Mittelalter 1150-1550. Köln, Weimar: Böhlau Verlag. 
Iyigun, M. (2008): "Luther and Suleyman," The Quarterly Journal of Economics, 123(4), 1465-1494.

Matsuyama, K. (1992): "Agricultural productivity, comparative advantage, and economic growth," Journal of economic theory, 58(2), 317-334.

Michalopoulos, S. (2012): "The origins of ethnolinguistic diversity," The American Economic Review, 102(4), 1508-1539.

Nicholas, D. (2009): The Northern Lands: Germanic Europe, C. 1270-c. 1500. Wiley-Blackwell.

Nunn, N., And D. Puga (2012): "Ruggedness: The blessing of bad geography in Africa," Review of Economics and Statistics, 94(1), 20-36.

Pfaff, S., ANd K. E. CorCoran (2012): "Piety, power, and the purse: religious economies theory and urban reform in the Holy Roman Empire," Journal for the Scientific Study of Religion, 51(4), 757-776.

Ramankutty, N., J. A. Foley, J. Norman, and K. McSweeney (2002): "The global distribution of cultivable lands: current patterns and sensitivity to possible climate change," Global Ecology and Biogeography, 11(5), 377-392.

Rashdall, H. (1895): The Universities of Europe in the Middle Ages: Salerno. Bologna. Paris, vol. 1. Clarendon Press.

RODRIK, D. (2008): One economics, many recipes: globalization, institutions, and economic growth. Princeton University Press.

Rubin, J. (2014): "Printing and Protestants: an empirical test of the role of printing in the Reformation," Review of Economics and Statistics, 96(2), 270-286.

SCRIBNER, R. W. (1994): "The Reformation in national context," in The Reformation in national context. Cambridge University Press.

Spenkuch, J. L. (2011): "The Protestant Ethic and Work: Micro Evidence from Contemporary Germany," University of Chicago, Chicago. 
TAlbert, R. J. (2000): Barrington Atlas of the Greek and Roman World: Mapby-map Directory, vol. 1. Princeton University Press.

TILly, C. (1992): Coercion, capital, and European states, AD 990-1992. Blackwell Oxford.

Vollrath, D. (2010): "A New Look at Agricultural Productivity and Economic Growth," University of Houston, Houston.

VRIES, J. D. (1984): European urbanization, 1500-1800. London: Methuen.

Wolfart, J. C. (2002): Religion, Government and Poltical Culture in Early Modern Germany: Lindau, 1520-1628. Palgrave MacMillan.

ZEumer, K. (1907): Quellensammlung zur Geschichte der deutschen Reichsverfassung in Mittelalter und Neuzeit, vol. 2. Mohr. 